\title{
Natural Geochemical Analogues for Carbon Dioxide Storage in Deep Geological Porous Reservoirs, a United Kingdom Perspective
}

\author{
R.S. Haszeldine', O. Quinn', G. England', M. Wilkinson' ', Z.K. Shipton², \\ J.P. Evans ${ }^{3}$, J. Heath ${ }^{3}$, L. Crossey ${ }^{4}$, C.J. Ballentine ${ }^{5}$ and C.M Graham ${ }^{1}$ \\ 1 School of GeoSciences, University of Edinburgh, EH9 3 JW Scotland - United Kingdom \\ 2 Divison of Earth Sciences, University of Glasgow, G12 8QQ, Scotland - United Kingdom \\ 3 Department of Geology, Utah State University, Logan, UT 84322-4505 - United States \\ 4 Dept of Earth and Planetary Sciences, University of New Mexico, Albuquerque, NM 87131 - United States \\ 5 Dept Earth Sciences, University of Manchester, Manchester, M13 9PL - United Kingdom \\ e-mail: stuart.haszeldine@ed.ac.uk - oliver.quinn@glg.ed.ac.uk - gavin.england@glg.ed.ac.uk - mark.wilkinson@glg.ed.ac.uk \\ z.shipton@earthsci.gla.ac.uk - jpevans@cc.usu.edu - Icrossey@unm.edu - chris.ballentine@man.ac.uk - cgraham@glg.ed.ac.uk
}

\begin{abstract}
Résumé - Analogues géochimiques naturels pour le stockage du dioxyde de carbone en réservoir géologique poreux profond : perspective pour le Royaume-Uni - La concentration élevée en $\mathrm{CO}_{2}$ atmosphérique participe au réchauffement climatique. Une mesure d'atténuation consiste à capter le $\mathrm{CO}_{2}$ émis par les centrales électriques qui utilisent des combustibles fossiles, et à le stocker dans des aquifères salins ou dans des gisements exploités d'hydrocarbures. Des projets de démonstration déjà en cours et des analyses techniques indiquent que cette mesure est viable. $\mathrm{Le} \mathrm{CO}_{2}$ doit rester confiné pendant au moins 10000 ans pour que cette option technologique ait un impact climatique. En vue de fournir une évaluation solide des performances d'un site de stockage, à l'échelle de temps indiquée, une approche possible est d'étudier les accumulations naturelles de $\mathrm{CO}_{2}$. Celles-ci sont en particulier capables de donner des informations sur les interactions roche$\mathrm{CO}_{2}$-saumure à des échelles de temps comprises entre le millier et la dizaine de millions d'années. Les champs de $\mathrm{CO}_{2}$ naturel en mer du Nord (Brae, Miller, Magnus), situés à $4000 \mathrm{~m}$ d'enfouissement et plus, ne montrent pas la néoformation des phases minérales souvent prédite par la modélisation géochimique. La calcite et les feldspaths peuvent constituer encore entre 5 et $20 \%$ des minéraux de la roche, tandis que la dawsonite n'est pas observée. Il en est de même pour des exemples de réservoirs de grès situés dans le sud-est australien et en Arizona. Il est possible qu'un état de déséquilibre thermodynamique se soit maintenu, de sorte que les modèles existants ne sont pas capables de prédire correctement les évolutions minéralogiques réelles, sur les durées pertinentes pour la séquestration du $\mathrm{CO}_{2}$. Ces modèles nécessitent une meilleure calibration. Les données expérimentales, à l'échéance de quelques mois, ou celles déduites des situations de récupération assistée $\left(\mathrm{CO}_{2}\right.$-EOR), à l'échéance de quelques dizaines années, sont en général trop courtes pour offrir toutes les calibrations nécessaires. En revanche, les analogues naturels peuvent aider à combler cette lacune. Le plateau du Colorado abrite un tel système naturel, où des gisements estimés à $100 \mathrm{Gm}^{3}$ de $\mathrm{CO}_{2}$ ont pu s'accumuler, à partir de sources vocaniques d'âge inférieur à 5 Ma.
\end{abstract}


L'érosion a porté à l'affleurement l'ensemble des roches et des structures concernées par le système : source, drain, réservoir, piège, couverture. De très gros pièges sont aujourd'hui observables, avec parfois une activité actuelle qui conduit à des sources de $\mathrm{CO}_{2}$ et à la formation de travertins. Des exemples à Salt Wash Green River, et le long de la faille de Moab, sont brièvement décrits. Ils montrent un phénomène intense de blanchiment de l'hématite avec redépôt local de celle-ci, une cimentation de carbonates avec une signature $\delta^{13} \mathrm{C}$ vers $-7 \%$ autour des zones d'origine du gaz, et des précipitations de silice susceptibles de sceller les zones d'échappement en crête de structure. Une modélisation précise des performances à long terme d'un site de stockage demande une compréhension accrue des chemins et des cinétiques réactionnels au sein des réservoirs et des roches de recouvrement. Il n'y a pas de prédiction vraiment solide à espérer en-dehors de cette approche.

\begin{abstract}
Natural Geochemical Analogues for Carbon Dioxide Storage in Deep Geological Porous Reservoirs, a United Kingdom Perspective - Elevated concentrations of atmospheric $\mathrm{CO}_{2}$ are implicated in global warming. Mitigation of this requires capture of $\mathrm{CO}_{2}$ from fossil fuel power sources and storage in subsurface aquifers or depleted hydrocarbon fields. Demonstration projects and financial analysis suggest that this is technologically feasible. $\mathrm{CO}_{2}$ must retained below ground for $10^{4}$ y into the future to enable the surface carbon cycle to reduce atmospheric $\mathrm{CO}_{2}$ levels. To provide robust predictions of the performance of disposal sites at the required timescale, one approach is to study natural $\mathrm{CO}_{2}$ accumulations, which give insight into rock-CO $\mathrm{CO}_{2}$-brine interactions over timescales of $10^{3}-5.10^{6} \mathrm{y} . \mathrm{In}$ contrast to geochemical modelling predictions, natural $\mathrm{CO}_{2}$ fields in the North Sea (Brae, Miller, Magnus, Sleipner), at $4.0 \mathrm{~km}$ and deeper, do not show the mineral products which are predicted to form. Calcite and feldspar still comprise 5-20\% of the rock, and dawsonite is absent. SE Australian and Arizona reservoir sandstones also do not fit to geochemical predictions. A state of disequilibrium possibly exists, so that existing geochemical modelling is not capable of accurately predicting kinetic-controlled and surface-chemistry controlled mineral dissolution or precipitation in natural subsurface sandstones on the required timescales. Improved calibration of models is required. Geochemical evidence from laboratory experiments (months to years duration), or from enhanced oil recovery (30 y duration) are again too short in timescale. To help to bridge the $10^{4}$ y gap, it may be useful to examine natural analogues $\left(10^{3}-10^{6} y\right)$, which span the timescale required for durable disposal. The Colorado Plateau is a natural $\mathrm{CO}_{2}$ system, analogous to an hydrocarbon system, where $100 \mathrm{Gm}^{3} \mathrm{CO}_{2}$ fields occur, sourced from 0-5 Ma volcanics. Deep erosion has exposed the sediments which formed $\mathrm{CO}_{2}$ source, $\mathrm{CO}_{2}$ carrier, $\mathrm{CO}_{2}$ reservoir, $\mathrm{CO}_{2}$ trap, $\mathrm{CO}_{2}$ seal. Some very large $\mathrm{CO}_{2}$ traps are now exhumed, and some are currently leaking to form cool travertine springs at the surface. Natural examples at Salt Wash Green River, and at Moab Fault are briefly described. These show extensive bleaching of haematite which may be locally redeposited, carbonate cementation $\delta^{13} \mathrm{C}-7 \%$ o around point sources, and silica precipitation, which may seal leak-off on buried anticline crests. Accurate geochemical modelling of the long-term performance of $\mathrm{CO}_{2}$ storage sites, requires improved understanding of $\mathrm{CO}_{2}$ reaction paths and reaction rates with aquifer reservoirs and with overlying seals. Robust prediction of disposal site performance is not possible without this.
\end{abstract}

\section{INTRODUCTION}

Carbon dioxide emissions have grown during industrialisation of the world (Mackenzie et al., 2001) and are prognosed to increase further. This is linked, by many climate workers, to the observed gradual increase of average world temperature of $0.6^{\circ} \mathrm{C}$ in the last $140 \mathrm{y}$. Six scenarios have been highlighted by the IPCC (2001) to investigate the climatic effects if human $\mathrm{CO}_{2}$ output is altered, or not altered, to meet atmospheric stabilization targets of $350,450,550,650$ and 750 parts per million by volume (ppmv). Predictions from a suite of climatic models suggest that the world will warm by 1.4 and $5.8^{\circ} \mathrm{C}$, and possibly by $9^{\circ} \mathrm{C}$ before 2100 as a consequence of $\mathrm{CO}_{2}$ and other greenhouse gas emissions (IPCC, 2001). Even if emissions are stabilised, and then reduced at "Kyoto" rates (such that industrialised $\mathrm{CO}_{2}$ emission is reduced to $5.2 \%$ below 1990 levels by 2012 and held at that rate), then the world is already committed to a continued rise of temperature, of at least $2^{\circ} \mathrm{C}$ over the next 100 y (Wigley, 1998) (Fig. 1). Thus short term (100 y) scenarios do not depend much on emissions reduction, but climatic changes after 2100 are greatly influenced by actions taken now to reduce $\mathrm{CO}_{2}$ (IPCC, 2001), which provide good value for money in avoiding much greater future expenditure (Yohe et al., 2004). These values of average temperature change inevitably disguise local more extreme variations, 
such as an increase in south Texas of up to $25^{\circ} \mathrm{F}\left(14^{\circ} \mathrm{C}\right)$ by 2100 (Parmesan, 2001). If these analyses are credible, then the industrialised world must cut $\mathrm{CO}_{2}$ emissions to about $40 \%$ of current values, and develop low carbon emissions industry and energy supply by 2060 . This may keep $\mathrm{CO}_{2}$ levels below $550 \mathrm{ppm}$, where environmental impacts are predicted to acceptable, based on scenario A1T reduced fossil fuel use (IPCC, 2001).

Reduction of $\mathrm{CO}_{2}$ emissions is currently an objective of United Kingdom energy policy (Foresight, 2002; DTI 2003). Multiple options are being pursued, such as improved insulation, energy efficiency, or electricity generation from renewable sources. One of these options is to continue burning of fossil fuels, but to store or sequester the emitted $\mathrm{CO}_{2}$ and dispose of that below ground in depleted hydrocarbon fields, or in deep saline aquifers (Holloway et al., 1996). Storage of $\mathrm{CO}_{2}$ in deep geological formations by injection into depleted hydrocarbon traps or regional saline aquifers could hold many years (decades to hundreds of years) of industrial $\mathrm{CO}_{2}$ generation. This is a particularly attractive possibility for the United Kingdom, which has access to many porous reservoirs and aquifers onshore and offshore, and a broad expertise in the fluid geology of hydrocarbon exploration and production. $\mathrm{A} \mathrm{CO}_{2}$ injection test site is operating offshore of Norway in the Utsira sand. Here, $\mathrm{CO}_{2}$ derived from condensate production is separated on an offshore platform and reinjected at a rate of $1 \mathrm{Mt} / \mathrm{y}$ into the $800 \mathrm{~m}$ Utsira sand saline aquifer. Extrapolating these single-borehole injection rates suggests that just 150 offshore boreholes could satisfy the United Kingdom's $\mathrm{CO}_{2}$ reduction obligations for Kyoto and beyond to 2020, using many components of proven technology, minimising both development risks and times.

The purpose of disposal is to slow the rate at which additional fossil $\mathrm{CO}_{2}$ enters the biosphere. At some future geological time, this $\mathrm{CO}_{2}$ will return to the surface through natural cycling. If this time is less than the recovery time needed for the biosphere, then no net environmental benefit will have been achieved. It is important to estimate the timespan needed for natural processes of $\mathrm{CO}_{2}$ cycling, to return the anthropogenic $\mathrm{CO}_{2}$ to its preindustrial level. That is the minimum time needed for subsurface $\mathrm{CO}_{2}$ disposal. Kheshgi et al. (1996) have simulated the recovery time needed (Fig. 2). If $\mathrm{CO}_{2}$ peaks at $550 \mathrm{ppm}$ in 2050, $2 \times$ the present atmosphere level (i.e. if $\mathrm{CO}_{2}$ emissions are halved by 2015), this timespan is $10^{3}$ y (IPCC, 2001, scenario A1B). If the rate of $\mathrm{CO}_{2}$ emission continues to increase on a fossil fuel intensive basis (IPCC, 2001, scenario A1F1), to exceed 1200 ppm by 2175, then the recovery time needed is longer than $10^{4} \mathrm{y}$. Simulation of $\mathrm{CO}_{2}$ storage has considered the acceptable retention times necessary to achieve such targets (Lindeberg, 2003) and concludes that $\mathrm{CO}_{2}$ must be retained for longer than 7000 y. Leakage rates from storage sites must be $0.01 \% / y$ or less (Hepple and Benson, 2003) to ensure that $\mathrm{CO}_{2}$ is stored for a sufficiently long timespan.

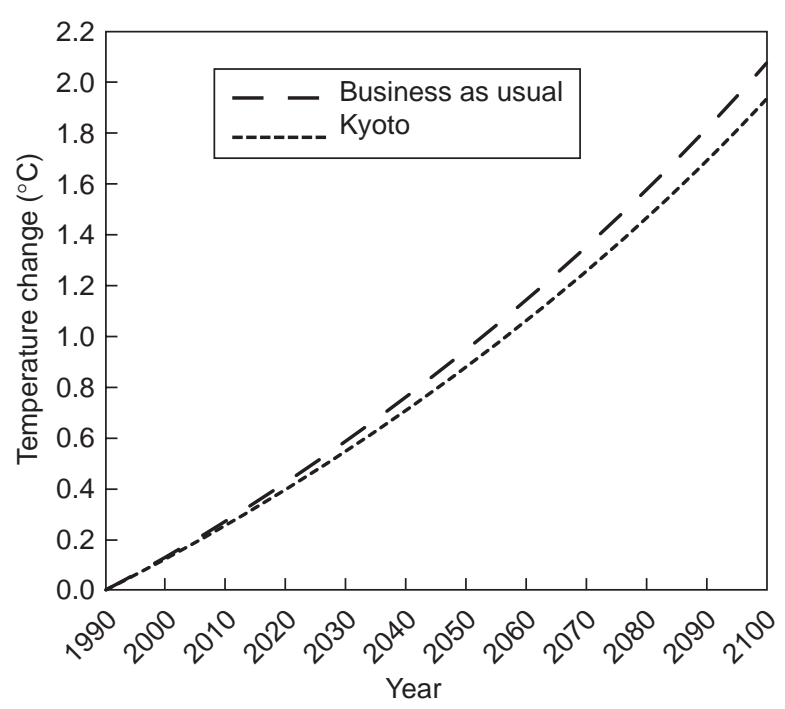

Figure 1

The rise of $\mathrm{CO}_{2}$ since industrialisation has already committed the world to a temperature rise of several centigrade, even if Kyoto agreements are fully enacted (from Wigley, 1998).

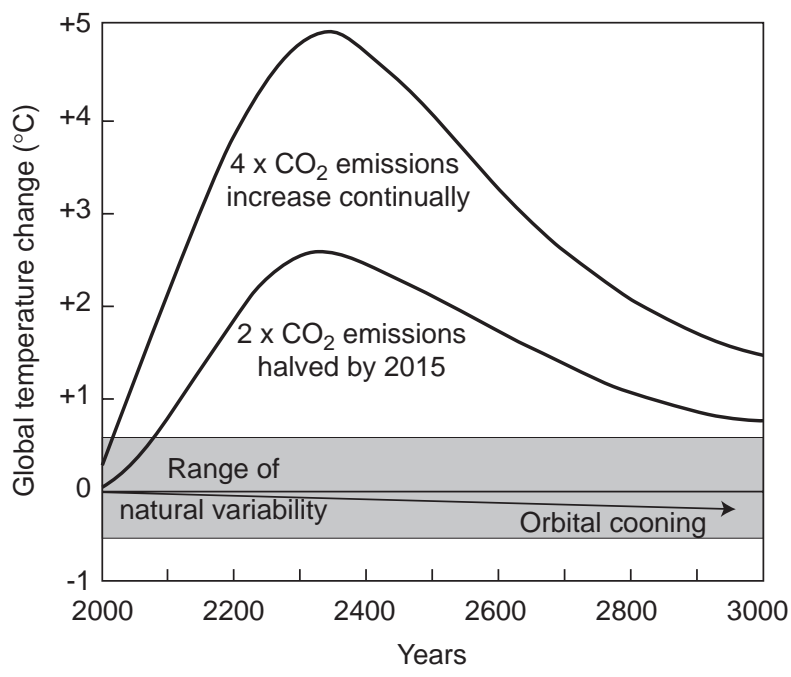

Figure 2

Simulations of temperature rise show that, just as with Figure 1, the world is committed to a continued increase in temperature. This takes many hundreds or, probably thousands, of years to decay back to pre-industrial values (from Kheshgi et al., 1996). 


\section{UNITED KINGDOM EMISSIONS AND OPPORTUNITIES}

Areally extensive and deep sedimentary basins exist both beneath the United Kingdom and offshore of the United Kingdom. The offshore basins are arguably better known geologically than the onshore basins because of intensive hydrocarbon exploration and drilling since 1964 (Glennie, 1998). More than 2000 boreholes have been drilled in the United Kingdom sector alone.

Total emissions by the United Kingdom in 2001 are cited as being $147 \mathrm{Mt} / \mathrm{y}$ carbon (565 Mt/y CO $\mathrm{CO}_{2}$ (IEA, 2004). An obvious possibility is to consider disposal in offshore or onshore sedimentary basins. The Sleipner field experiment, offshore from Norway, commenced in 1996. Statoil reinject $\mathrm{CO}_{2}$, produced from a $3 \mathrm{~km}$ deep Jurassic condensate, into the Utsira sand a $1.0 \mathrm{~km}$ deep saline aquifer (Korbol et al., 1995). It is clearly possible, in engineering terms, to inject $1 \mathrm{Mt} / \mathrm{y} \mathrm{CO}$ into the subsurface from only one borehole. Consequently, if 150 boreholes could be engineered, then all the yearly $\mathrm{CO}_{2}$ emissions from all of the United Kingdom coal-fuel power stations could be disposed of (Fig. 3). Injection of $\mathrm{CO}_{2}$ into depleted oilfields is attractive as a first step-because of both top seal capability and because of the economic side-benefit of extra produced oil. However simple calculation of the limited oilfield volume shows that this can be only a 5-10 y interim measure, hosting a maximum of $2.6 \mathrm{Gt} \mathrm{CO}_{2}$ in depleted offshore United Kingdom oilfields
(Holloway et al., 1996). Long term storage strategy requires saline aquifers to be used, which have not previously held hydrocarbons or $\mathrm{CO}_{2}$ for geological timescales. Offshore United Kingdom aquifers could host as much as $240 \mathrm{Gt} \mathrm{CO}_{2}$, and store $50 \%$ of the annual United Kingdom $\mathrm{CO}_{2}$ emissions for many decades (Holloway et al., 1996).

The costs to a national economy of $\mathrm{CO}_{2}$ disposal are subjectively considered to be large because of the cost of $\mathrm{CO}_{2}$ capture at power stations. However analysis by Ash et al., (2002) using United Kingdom Treasury approaches, shows that $\mathrm{CO}_{2}$ sequestration into deep geological settings is likely to be cheaper than offshore renewable wind power. This implies a small rise of $14 \%$ in retail electricity prices, with a national carbon tax being imposed of $£ 31 / \mathrm{t} \mathrm{CO}_{2}$ (Fig. 4). Significantly Ash et al., (2002) calculated that the overall effect of $\mathrm{CO}_{2}$ taxation was economically neutral to the United Kingdom economy, because of additional employment and economic opportunities created by the new $\mathrm{CO}_{2}$ disposal industry. The cost would be less than $1 \%$ of gross domestic product for the next $100 \mathrm{y}$, compared to a typical annual growth of $2-3 \% / y$.

\section{SLEIPNER EXPERIMENT}

Since 1996, at Sleipner West field, the oil company Statoil has reinjected $\mathrm{CO}_{2}$ from the $3.3 \mathrm{~km}$ deep mid-Jurassic age Hugin formation into sands and muds of the $1.0 \mathrm{~km}$ deep

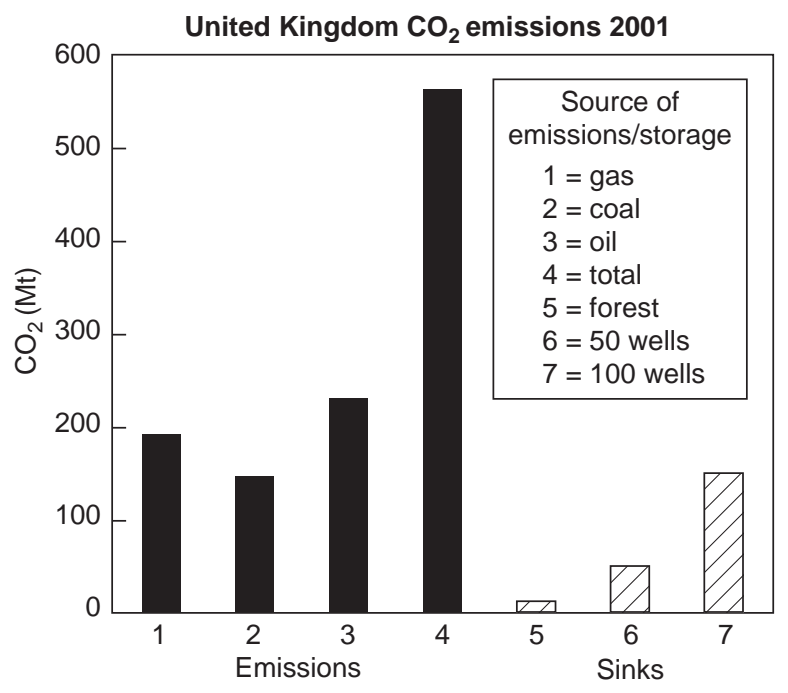

Figure 3

United Kingdom emissions of $\mathrm{CO}_{2}$ during 2001 totalled about $565 \mathrm{Mt}$. If several boreholes comparable to that of the Sleipner experiment were engineered, then 150 such boreholes could accommodate the coal-power emissions from all the United Kingdom. This greatly exceeds the potential for doubling the forested area of the UK-which could sequester $11 \mathrm{Mt} / \mathrm{yCO}_{2}$, but only during tree growth.

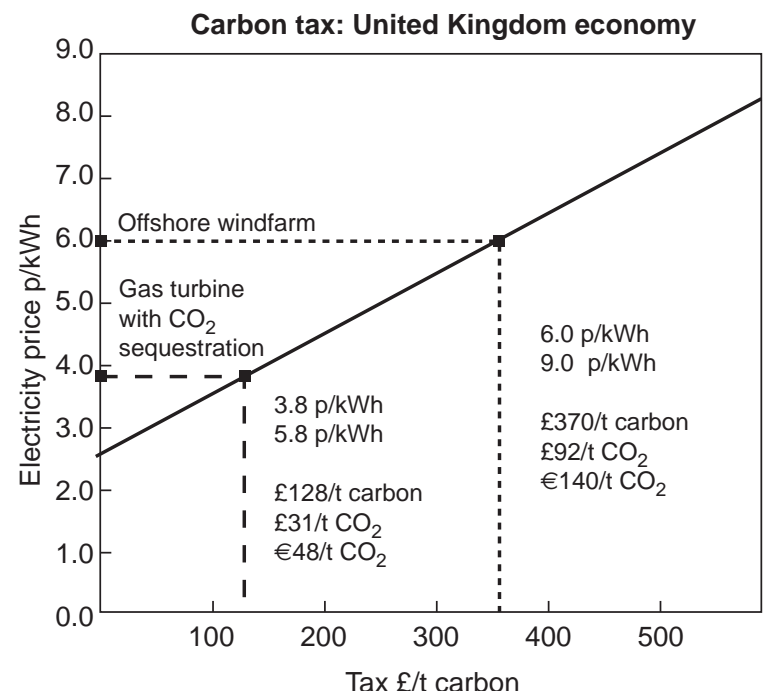

Figure 4

Storage of $\mathrm{CO}_{2}$ is sometimes considered uneconomic because of the additional direct costs involved, mainly of $\mathrm{CO}_{2}$ capture. However a more complete economic analysis, by Ash et al., (2002), suggests that a United Kingdom carbon tax of $£ 31 / t \mathrm{CO}_{2}$ would be economically neutral, and provide electricity more cheaply than offshore windfarms. 
upper Miocene Utsira formation, which is about $200 \mathrm{~m}$ thick (Korbol and Kaddour, 1995). Before injection, this sandstone did not form a natural reservoir for geological accumulations of oil, gas, or $\mathrm{CO}_{2}$ at this site. This is an archetypal example to investigate the concept of $\mathrm{CO}_{2}$ disposal into a "deep saline aquifer". Seismic reflection surveys have been shot across the site in 1994 before any engineered disturbance, again in 1999 after three years of $\mathrm{CO}_{2}$ injection, and again in 2001 and 2002. By subtracting the results of the series of surveys, it is possible to make images of the net disturbance effect, consequent on the low-density supercritical $\mathrm{CO}_{2}$ (density about $0.6 \mathrm{~g} / \mathrm{cm}^{3}$ ), filling porespace. These images clearly show that $\mathrm{CO}_{2}$ remains in the sandstone, although rapid leakage has occurred through intra-reservoir mudrocks (Chadwick et al., 2003).

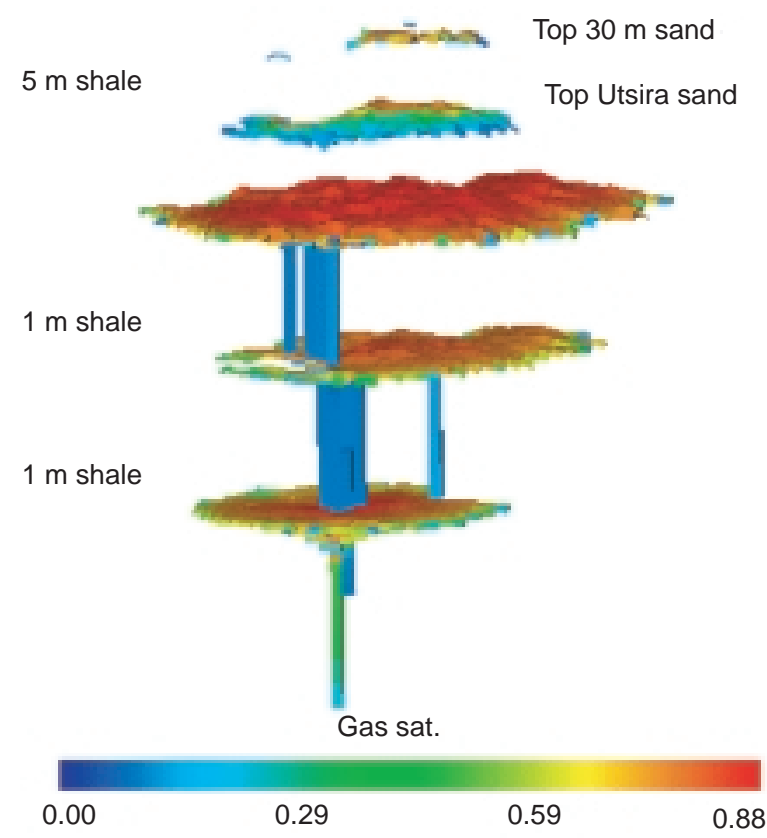

Figure 5

The experiment of injection at Sleipner retains $\mathrm{CO}_{2}$ for the first few years of operation. Seismic monitoring surveys by Zweigel et al., (2001) shows that $\mathrm{CO}_{2}$ has leaked through thin mudstones within the aquifer, but has been retained by the thick top-seal mudrock.

However Zweigel et al., (2001) and Chadwick et al., (2003) show that above the top of the main Utsira sandstone mudrock seal, the seismic difference survey shows small reflectors, similar in amplitude character to those in the bulk of the sandstone resulting from $\mathrm{CO}_{2}$ injection. This is exactly the type of result to be expected if some $\mathrm{CO}_{2}$ had already leaked into, and through, a $5 \mathrm{~m}$ mudrock top seal into the overlying $30 \mathrm{~m}$ "Sand Wedge". Processing of the two surveys by Zweigel et al., (2001, Fig. 5) provides a consistent picture that $1 \mathrm{~m}$ thick mudrocks within the Utsira formation cannot retain $\mathrm{CO}_{2}$, only delay its buoyant rise, and neither has the $5 \mathrm{~m}$ mudrock formed a robust seal (Fig. 5). There is no evidence that $\mathrm{CO}_{2}$ has leaked through the main sealing rock of the overlying Nordland Group mudrocks. However, no natural $\mathrm{CO}_{2}$ accumulations exist at shallow depth in the North Sea, so there is no natural analogue evidence to show how this particular mudrock seal may perform over geological timescales. Additionally, geomechanical modelling simulation of mudrock top seals performed at Lawrence Livermore laboratories, and presented by Johnson et al. (2003), suggests that thin mudrock top seals will be prone to fracture in the initial stages of containing a buoyant $\mathrm{CO}_{2}$ fluid column.

Chadwick et al., (2003) show that $\mathrm{CO}_{2}$ injection has formed a vertical chimney, within the Utsira formation sandstones and mudrocks, of increased relative permeability. This points to physical leakage through thin mudrock seals being a short-term (decades) problem for saline aquifer disposal. This is not necessarily fatal to the promising concept, but is a problem which needs to be assessed and quantified. At present the question remains-will leakage occur at all through the mudrock top seal, and if so at what rate? Using the logic of Hepple and Benson (2003), a leakage rate of less than $0.01 \% / y$ means that zero leakage must be detected at the Utsira formation injection site until 2005, and to confirm less that $0.001 \% / y$ leakage, then no leakage must be detected until 2023 (Chadwick, pers. comm., 2004). Either of these target leakage rates, if durable over millenia, would be successful for long term storage.

Over longer timescales of $10^{2}-10^{5} \mathrm{y}$, will there be geochemical interaction between the $\mathrm{CO}_{2}$ saturated aquifer waters and the overlying mudrock? In many fluid migration systems there is a possibility that "fingering" of interaction may occur, to produce fluid breakthrough at much shorter timescales than equilibrium predictions would suggest. It is not known how $\mathrm{CO}_{2}$ will interact on these timescales with the reactive shallow-buried smectite clays of the Utsira formation and similar top seal mudrocks in the North Sea and other sedimentary basins. Modelling by Johnson and Nitao (2003) suggests that geochemical reaction will occur on timescales of 1-120 y to reduce mudrock seal permeability. However initial geological investigation by the present authors of rock mineralogy in North Sea examples does not confirm the suite of predicted minerals.

\section{PREDICTED MINERAL REACTIONS}

$\mathrm{CO}_{2}$-induced reactions, particularly in brackish or saline fluids (Shmulovich et al., 1995), are likely to involve acid hydrolysis of rock-forming minerals; for example: anorthite + $2 \mathrm{H}_{2} \mathrm{O}+\mathrm{CO}_{2} \rightarrow$ kaolin + calcite. Studies of $\mathrm{CO}_{2}$ interaction 
with reservoirs have used computer simulations (Gunter, 1996; Knauss et al., 2001; Johnson and Nitao, 2003), indicating that feldspars and micas are potentially very reactive to $\mathrm{CO}_{2}$ on timescales of 10-400 y. For example, with trace (ppm) $\mathrm{CO}_{2}$, feldspar + clay $+\mathrm{CO}_{2} \rightarrow$ [laumontite/ prehnite/chlinochlore] depending on salinity and cations present. However, laumontite and other zeolites are unstable in $\mathrm{CO}_{2}$ concentrations more than tens ppm, so that: feldspar + clay $+\mathrm{CO}_{2} \rightarrow$ kaolin + muscovite + carbonates + quartz. More recent analyses have predicted dawsonite to be the stable carbonate formed (Knauss et al., 2001). Simulations of clay mineral interactions have been less sophisticated, often due to the lack of specific thermodynamic data. (Gunter et al., 1996) found that glauconite clay (annite as a proxy) dissolved 5-10 times more rapidly than feldspar, to produce siderite and muscovite. Thus smectite and glauconite clays would be expected to be amongst the most reactive.

Autoclave laboratory experiments have not confirmed this theoretical modelling, because elevated temperatures reduce $\mathrm{CO}_{2}$ solubility, whereas realistic lower temperatures greatly decrease reaction rates to unfeasibly long timescales. We are not aware of any definitive field study of an in situ natural $\mathrm{CO}_{2}$ reservoir to confirm the modelled predictions. Some mineral and petrographic data has been report from $\mathrm{CO}_{2}$ springs in Arizona, which suggests that stratabound layers of high $\mathrm{CO}_{2}$ concentration may control the occurrence of dawsonite, for example (Moore et al., 2003). In the Otway Basin, $\mathrm{CO}_{2}$ has charged the Ladbroke Grove field less than $1 \mathrm{Ma}$ ago with 26-57\% $\mathrm{CO}_{2}$, dissolving rock fragments, calcite, chlorite and producing kaolin, quartz and small concretions of $\mathrm{Fe}+\mathrm{Mg}$-carbonate above the GWC from lithic sandstones. By contrast, the adjacent Katnook field has no $\mathrm{CO}_{2}$, and retains feldspar, rock fragments, chlorite and calcite.

This is problematic for predictive modelling, because it is apparent that natural systems are certainly greatly influenced by a suite of "kinetic" factors. Computer models of low temperature processes are based on combinations of kinetic rates of precipitation and dissolution, and equilibrium. The choice of kinetic constants and pathways is difficult, as these factors vary with mineral solid solution, aqueous fluid composition, mineral microsurface area, and brine salt content. Consequently, nature may differ from modelling. This is important because growth of these different minerals can reduce, or enhance, rock porosity and permeability - and thus improve or worsen $\mathrm{CO}_{2}$ retention in a sequestration setting. Geochemical modelling results typically predict different mineral assemblages to occur with:

- different $\mathrm{CO}_{2}$ concentrations;

- different rock mineralogies;

- different reaction times.

Studies of mineral weathering at the earth's surface can be used as analogous processes-with varying $\mathrm{CO}_{2}$ content and mineral-to-water ratio. Many authors have highlighted observations that natural weathering rates over thousands of years, or much longer duration, are very significantly slower than mineral reaction rates derived from experiments on unweathered material (Annbeek, 1992; Velbel 1993; Lee et al., 1998). White and Brantley (2003) showed experimentally that weathering rate in $\mathrm{CO}_{2}$ rich waters decreases exponentially, as a power-law rate, with duration of weathering, for plagioclase and for other major rock-forming silicates. Experimental reaction rates are several orders of magnitude faster than rates derived from nature. Consequently, rates derived from laboratory experiments are only a general guide to rates in natural systems, not an exact guide. Laboratory rates are always faster than rates for naturally weathered minerals, usually by a factor of $10^{2}$, and as much as $10^{6}$ in short term experiments (days or weeks). The importance of this is that the rapid rates of mineral reaction and $\mathrm{CO}_{2}$ sequestration predicted by modelling do not fit observations of real $\mathrm{CO}_{2}$ aquifers, so that prediction of rapid mineral precipitation will be unreliable. However the long-term dis-equilibrium of minerals with $\mathrm{CO}_{2}$ observed in real aquifers is very compatible with the processes measured by White and Brantley (2003).

Geochemical interactions between $\mathrm{CO}_{2}$ (aq) and rock forming minerals are very likely to occur, involving both dissolution and precipitation. The problem is to understand, and predict the rates and mineral products of these reactions at the low temperatures prevailing in $\mathrm{CO}_{2}$ disposal $\left(30-100^{\circ} \mathrm{C}\right)$. At such low temperatures, predictions from equilibrium thermodynamics are unreliable. Overall reaction sequences at cool temperatures are dominated by influences such as: reactive surface area, age of reactive surface, grain coating, grain micro-porosity, low fluid-to-mineral ratios. The final effect can be kinetically slow weathering close to thermodynamic equilibrium. Modelled predictions can differ greatly from reality. For example. it has already been noted that the dawsonite predicted by geochemical models (Knauss et al., 2001) does not occur widely in nature, and further natural examples from $\mathrm{CO}_{2}$ rich oilfields (below) show that in many cases dawsonite, or zeolites, have not been identified at all. Particularly important are the rates of reactions. For example these may determine if kinetically-rapid dissolution of mineral (A) may outpace equilibrium-favoured precipitation of mineral (B). It is notable that overall rates of reactions depend greatly on the experimental dataset used within a geochemical model, whereas rates of weathering at cool temperatures in nature may be $10^{6}$ times slower. Being able to demonstrate robust prediction of reaction routes and rates is a key problem, if $\mathrm{CO}_{2}$ sequestration within minerals is to gain industrial-scale acceptability with government regulators.

One route to demonstrating that geochemical models can make valid predictions into the future, is to calibrate modelling softwares against natural $\mathrm{CO}_{2}$ systems which have been active for the required $10^{4}$ year timescales. When a model can reproduce a known natural system, it can then be validated against a different, but related, natural system. If successful, then the model can form a useful predictor, suitable for evaluating $\mathrm{CO}_{2}$ retention or leakage. 


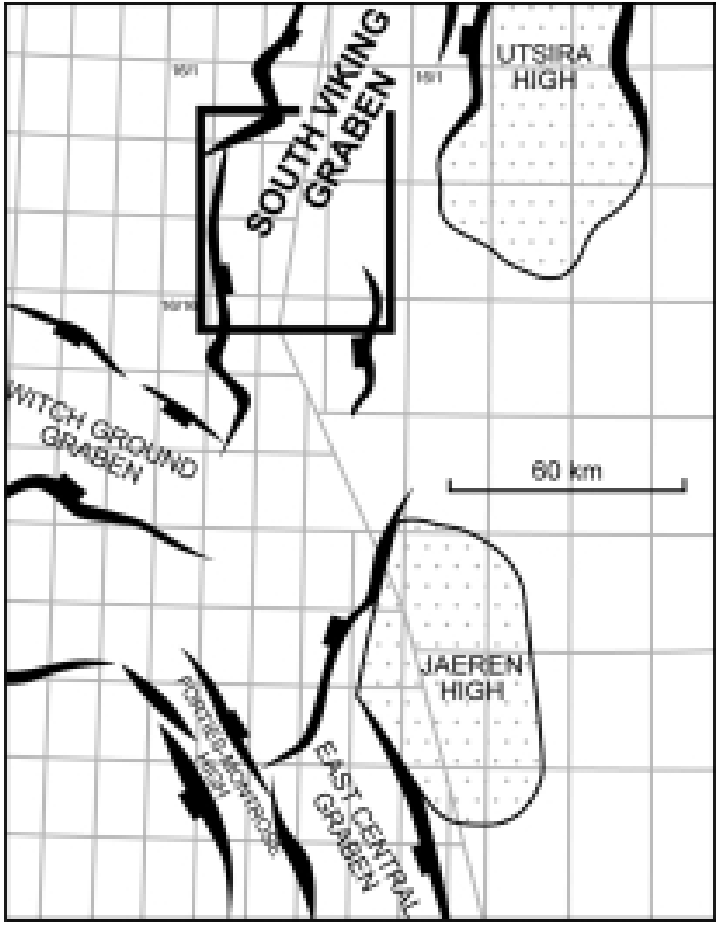

Figure 6

The North Sea contains several hydrocarbon fields with naturally high $\mathrm{CO}_{2}$, ranging $15-60 \mathrm{~mol} \%$. These are all positioned in the southwest Viking Graben, with the eastern being Sleipner. Mineral cements in these sandstone aquifers show little to no sign of interaction or equilibration with $\mathrm{CO}_{2}$ over millions of years.

\section{NATURAL EXAMPLES: UNITED KINGDOM OILFIELDS}

Several fields in the United Kingdom offshore (Fig. 6) are known to contain naturally high contents of $\mathrm{CO}_{2}$. A grouping of fields all contain high $\mathrm{CO}_{2}$ : South Brae (35 mol\%), Central Brae (30 mol\%), Miller (50 mol\%), Kingfisher (14 mol\%), Tiffany, Toni, Thelma (10 mol\%), (Fletcher, 2003a, 2003b; Gambardo and Donagemma, 2003; Spence and Kreutz, 2003; Baines and Worden, 2004) and the adjacent Sleipner west (9\%), site of the Norwegian injection experiment (Ranaweera, 1987; Korbol 1995). The Brae and Miller fields have been studied petrographically by McLaughlin et al. (1996), Marchand et al. (2001). Miller comprises $68 \%$ quartz sandstone, with $10 \%$ lithics, $5 \%$ feldspar. Cements are shallow burial calcite cement (5\%) retained in concretions, extensive quartz cement (10\%), with minor late dispersed calcite (2\%) all values include porosity. The late carbonate cement has a potentially distinctive signature of $\delta^{13} \mathrm{C}-8 \%$ (Baines and Worden, 2004). This is similar to $\delta^{13} \mathrm{C}-7 \%$ values considered to represent upper mantle degassing $\mathrm{CO}_{2}$ (Galimov, 1968; Fuex and Baker, 1973).

The Magnus field (Macaulay et al., 1992, 1993) has only $2 \mathrm{~mol} \% \mathrm{CO}_{2}$ in the hydrocarbon zone, is a $65 \%$ quartz sandstone, with $16 \%$ feldspar, $3 \%$ lithics, cemented by $4 \%$ quartz, $8 \%$ carbonate $4 \%$ clay. The carbonate is shallow to mid burial with isotopic signatures of $\delta^{13} \mathrm{C}-12 \%$.

A brief report of Sleipner Vest petrography by Ranaweera (1987), states that the mid-Jurassic Hugin Formation $\mathrm{CO}_{2}$ sandstone contains orthoclase, microcline and plagioclase feldspars, with minor lithic volcanic and grantic grains, and even altered glauconite. Again, this is not a mineral assemblage in equilibrium with high $\mathrm{CO}_{2}$ porewater-especially as the experiments of Gunter et al., (1996) suggested that glauconite would react within a very few years.

Significantly, neither Miller, Magnus, nor Sleipner Vest fields show present-day evidence of extensive dissolution of carbonate from a $\mathrm{CO}_{2}$ charge, zeolites or dawsonite have not been identified in any field, and K-feldspar co-exists with $\mathrm{CO}_{2}$ at the present day. No field has precipitated extensive deep burial carbonate cement as a result of $\mathrm{CO}_{2}$ being sequestered by natural processes. All of these effects appear to be out-of-equilibrium with the significant $\mathrm{CO}_{2}$ contents and history, even though present day burial temperatures are about $100^{\circ} \mathrm{C}-120^{\circ} \mathrm{C}$. It is possible that equilibrium geochemistry is not the dominating factor in predicting $\mathrm{CO}_{2}$ sequestration reactions.

\section{NATURAL EXHUMED EXAMPLES: COLORADO PLATEAU}

The uplifted Colorado Plateau area of the United States contains a natural $\mathrm{CO}_{2}$ basin system, where zones of $\mathrm{CO}_{2}$ input, regional migration in saline aquifers, ancient $\mathrm{CO}_{2}$ traps, and modern $\mathrm{CO}_{2}$ leakage up faults are all exposed today in 3D. The Colorado Plateau of the United States (Fig. 7) hosts many giant accumulations of $\mathrm{CO}_{2}$ at the present day (Allis et al., 2001). The sandstone aquifers of this foreland basin, and their mudrock seals are uniquely uplifted and dissected by canyon erosion. The $\mathrm{CO}_{2}$ system has probably been active for $5 \mathrm{Ma}$, and may have been active for 15 $\mathrm{Ma}$, and is still active today. Within this exhumed regional system, we can choose specific locations (Fig. 8) enabling us to examine and sample the effects of the $\mathrm{CO}_{2}$-rock-water geochemical system at several structural levels.

We make analogy with the concept of "hydrocarbon systems" (Magoon and Valin, 1994) within sedimentary basins, where it is possible to define: hydrocarbon source, timing, migration route, reservoir and leakage. In Colorado, we are examining a $\mathrm{CO}_{2}$ system, to locate $\mathrm{CO}_{2}$ sources, examine migration routes, and can examine traps, reservoirs, and seals which contain hydrocarbon $+\mathrm{CO}_{2}+$ brine, and contrast those with sites which were exposed simply to $\mathrm{CO}_{2}+$ brine. 


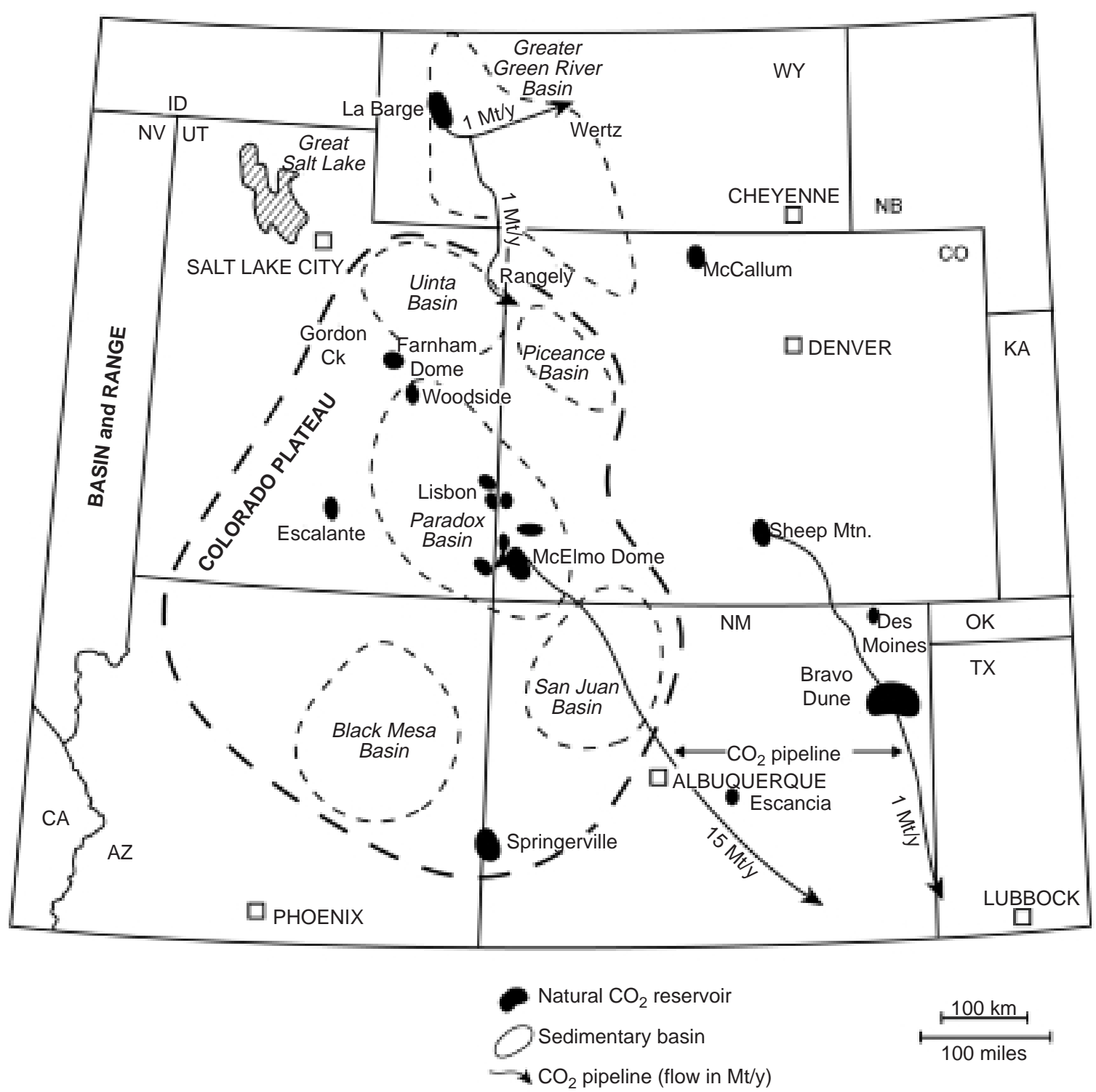

Figure 7

The Colorado Plateau of United States is anomalous in hosting many very large natural accumulations of $\mathrm{CO}_{2}$. This region is here viewed as a " $\mathrm{CO}_{2}$ system" where $\mathrm{CO}_{2}+$ mantle helium are supplied by recent volcanism derived from the upper and deep mantle (from Allis et al., 2001).

\subsection{Geological Setting}

Because of epeiric uplift of the Colorado Plateau in the past $5 \mathrm{Ma}$, kilometres of erosion have occurred to expose the sediments; regional deformation is minimal, and the fundamental geological history is well-known (Hintze, 1988; Stokes, 1988). The Mesozoic stratigraphy is similar in the adjacent states of SE Utah, Arizona, Colorado and Wyoming (Fig. 9). During Cambrian to Mississippian times Utah and Arizona accumulated sediments on the passive western continental margin of Laurentia. This was disrupted by the Devonian Antler Orogeny accretion of an island arc, which thrusted deepwater sediments eastward. Carboniferous sediments accumulated in a NW-SE depocentre adjacent to the Uncompahgre basement upflift of the "ancestral Rockies" formed by the Alleghanian Orogeny collision of Laurentia and Gondwana. South-east Utah is underlain by the Paradox Basin, where thick Pennsylvanian salt, and multiple oil source rocks (Huntoon et al., 1999), accumulated. As eastdipping subduction commenced, Mesozoic sediments accumulated as layer-cake stratigraphy in a NNE-SSW foreland basin, interrupted by the microcontinent accretion in the Sonoma and Nevadan Orogenies. The Sevier Orogeny associated with the largest compression, by accretion of the Sierra 


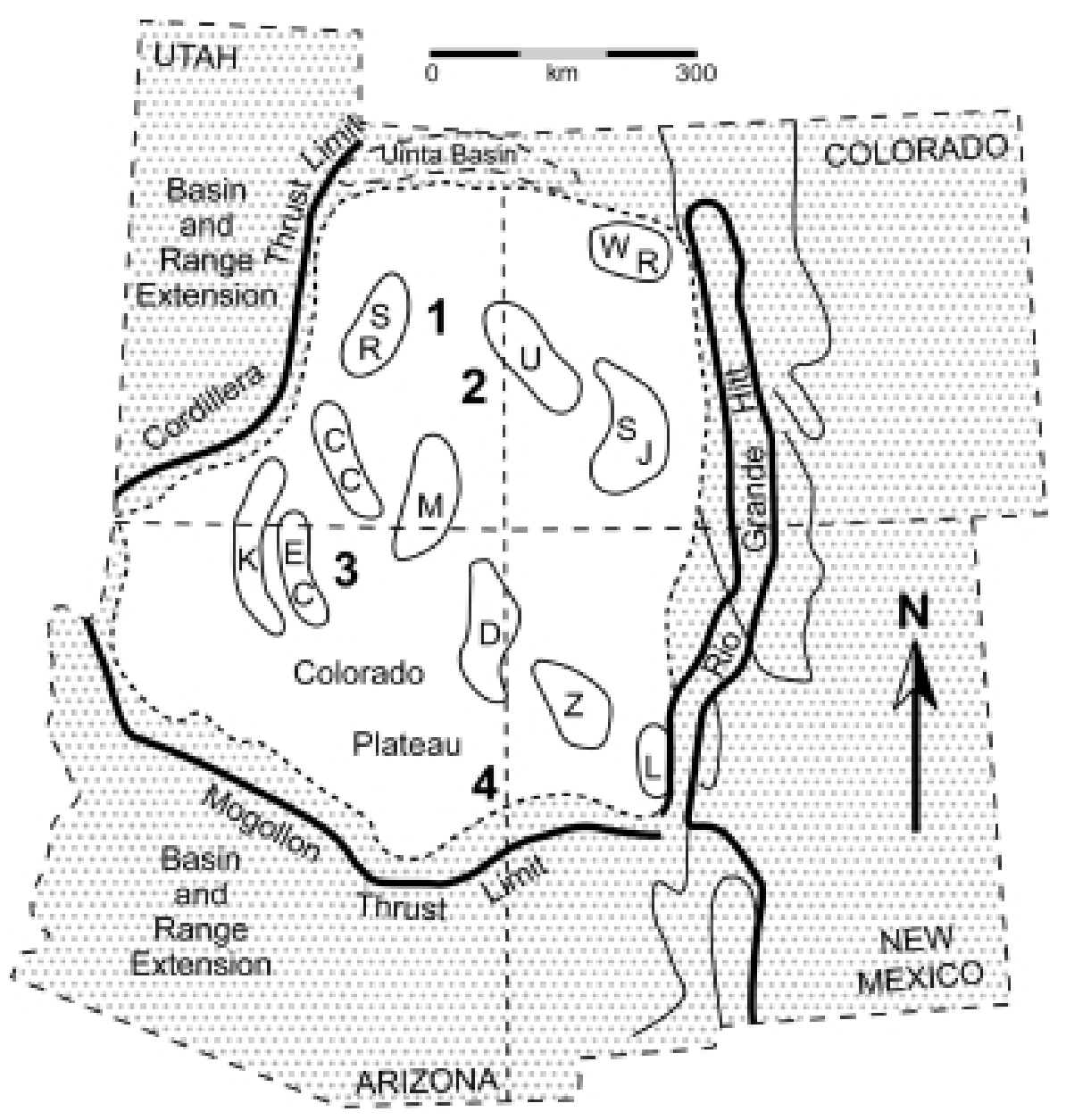

Figure 8

The Colorado Plateau is a minimally-deformed block of Mesozoic sediments, bounded to the west by active Basin and Range extension, and to the east by the Rio Grande Rift. This rift formed by clockwise rotation of the Colorado Plateau, and dissects Mesozoic Rocky Mountain uplifts. The Paradox Basin contains Carboniferous oil source rocks, which possibly supplied tar sands in south Utah. The Uinta Basin contains Eocene source rocks for oil, which migrated vertically, and possibly southwards. Numbers refer to $\mathrm{CO}_{2}$ spring localities discussed in the text: 1, Salt Wash and Crystal Geyser; 2, Moab anticline; 3, Grand Canyon; 4, Springerville.

arc, formed folds and thin-skin thrusts as far east as Wyoming. Foreland basin sediments deposited during this early Triassic-end Cretaceous period are targets for study, as they form laterally persistent beds for tens kilometres, which could act as regional carrier beds for hydrocarbons, $\mathrm{CO}_{2}$ or $\mathrm{H}_{2} \mathrm{~S}$. During the final stages of the Sevier episode, "Laramide" thick-skin tectonics caused relative uplift of basement blocks (Hintze, 1988 (Fig. 8)) in the Sevier foreland. These produced large open antiform growth structures, on a tens $\mathrm{km}$ scale, which are today expressed as large reverse-faults or monoclines (Figs. 8 and 10). These subsequently acted as very large (super-giant?) traps for $\mathrm{CO}_{2}$, and possibly for hydrocarbons (Beitler et al., 2003), which have been exhumed due to subsequent Colorado Plateau uplift. The Uinta Basin overlies a late pre-Cambrian aulacogen (Stokes, 1986), and formed by $7.6 \mathrm{~km}$ post-Cretaceous subsidence adjacent to one such uplift, generating oil from the world-class Eocene Green River formation. Oil has also been generated in the Paradox Basin from a suite of source rocks, ranging from Pennsylvanian Phosphoria formation, through lower Cretaceous marine Mancos shale and upper Cretaceous shoreline deposits of the Mesaverde Group. Oil migrated radially away from the Uinta depocentre and may have moved regionally southwards into this study area (Stokes 1988, Fig. 13.1) —also forming vertical bitumen dykes (locally known as gilsonite) by vertical overpressure leak-off along the Uinta axis. Oil migration, possibly from a number of source rocks (Fig. 9) has formed small subsurface fields, surface seeps around the eroded basement uplifts (breached traps), and the supergiant field, now expressed as surface 7 Gbbl Tar Sands in uppermost Permian sandstones of southern Utah (Huntoon et al., 1999). This was probably derived from the Mississipian Deseret Limestone within the local Paradox Basin, and migrated via the Permian White 


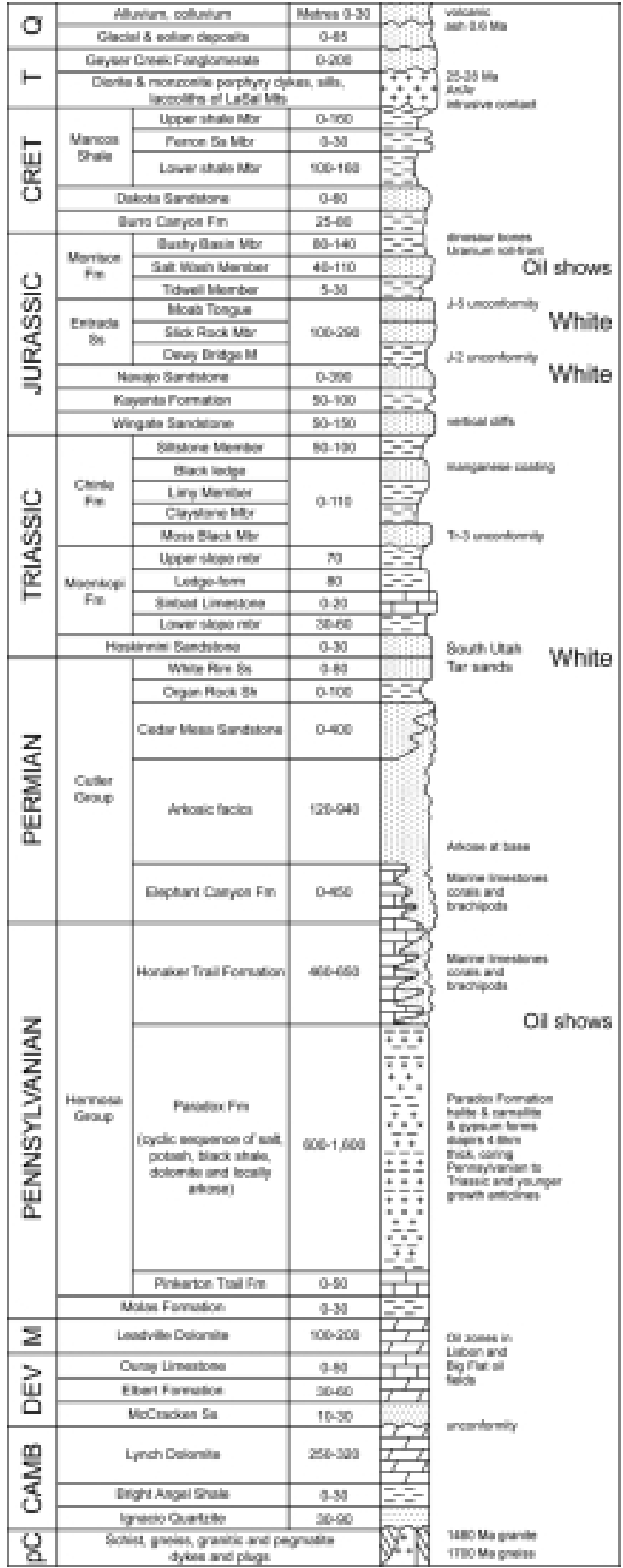

Figure 9

Simplified stratigraphic column of post-Cambrian lithologies and Formations in the Moab area. Modified from Hintze (1988). Similar stratigraphy, with local variations, exists in the Colorado Plateau region. The column also shows stratigraphic locations of oil shows, world-class tar sands, and regionally bleached sandstones.
Rim sandstones as carrier beds in the mid Tertiary. Another tar sand, possibly with $12 \mathrm{Gbbl}$ of oil occurs in the overlying Hoskinnnini Member of the Triassic Cutler Group (Fig. 9). Post-Triassic movement over pre-salt basement lineaments have produced large fault and antiform structures in the Paradox Basin. Some of these formed $\mathrm{CO}_{2}$ traps, which are now exhumed at the surface in $3 \mathrm{D}$, and may have also hosted some hydrocarbon (see also Beitler et al., 2003).

Explosive dacite and rhyolite volcanism occurred in western Utah from 40-15 Ma, related to plate subduction on the western United States. Renewed volcanism, of alkalibasalts, together with lamproites, has occurred from 5-0 Ma (Hamblin, 1994). It is this rift volcanism, which we consider to supply present-day $\mathrm{CO}_{2}$ and $\mathrm{He}$ accumulations. This province is unusual because of its giant $\mathrm{CO}_{2}$ accumulations (Allis, 2001), the largest $\mathrm{CO}_{2}$ field in Utah is Escalante, with $100 \mathrm{Gm}^{3}$ (4 tcf), comparable in volume to the North Sea Leman gasfield, and Bravo Dome $\mathrm{CO}_{2}$ accumulation in New Mexico contains $200 \mathrm{Gm}^{3}$ (8 tcf) recoverable $\mathrm{CO}_{2}$ (Roberts and Godfrey, 1994).

The Colorado Plateau has been uplifted by $2 \mathrm{~km}$ in the last $6 \mathrm{Ma}$ (Pederson et al., 2002), and crust has thinned to the west by extension, producing the Basin and Range province. Rotation of the Colorado Plateau clockwise has enabled opening of the Rio Grande Rift east of the Plateau. Faulting along basement structures within the Plateau has produced very large (km throw) normal and monoclinal structures; faulting continues to Quaternary time, shown by faults cutting radiometrically-dated lavas at Vulcan's Throne in the Grand Canyon.

\subsection{Cool Springs, Helium, and Travertines}

$\mathrm{CO}_{2}$ has been, and is, leaking off after migration into deep traps. Erosion of the plateau has enabled $\mathrm{CO}_{2}$-bearing brines to drain vertically and laterally into rapidly eroded canyons. These effects produce cool $\mathrm{CO}_{2}$ springs, with abundant travertine. At the north and west of the Plateau, a suite of such springs at Salt Wash, Green River (Baer and Rigby, 1978) exhale saline water with $\mathrm{CO}_{2}$ and minor $\mathrm{H}_{2} \mathrm{~S}$. Heath (2003) and Shipton et al., (2005) show that waters are very saline 13.8-21.2 eq wt\%, diluted in near-surface aquifers by by modern meteorically-derived waters. $95-99 \%$ of the gas is $\mathrm{CO}_{2}$, with minor $\mathrm{N}_{2} \mathrm{Ar}, \mathrm{He}$ and $\mathrm{H}_{2} \mathrm{~S}$. He values of $\mathrm{R} / \mathrm{Ra}$ are 0.302 , indicating a crustal component.

To the south and east of the Plateau, Crossey (2002) has examined modern waters from cold seeps in the Grand Canyon (3 on Fig. 8), which precipitate extensive travertines in association with limestone/shale contacts and basement faults. Analyses of ${ }^{3} \mathrm{He} /{ }^{4} \mathrm{He}$ ratios with $0.15 \mathrm{R} / \mathrm{Ra}$ show a mantle signature, ${ }^{87} \mathrm{Sr} /{ }^{86} \mathrm{Sr}$ values show radiogenic ranges from 0.710 to 0.728 , and $\delta^{18} \mathrm{O}$ of water is meteoric. A mixing can be envisaged of shallow active groundwater flow, with deeper "old" waters carrying $\mathrm{CO}_{2}$; these become enriched in 


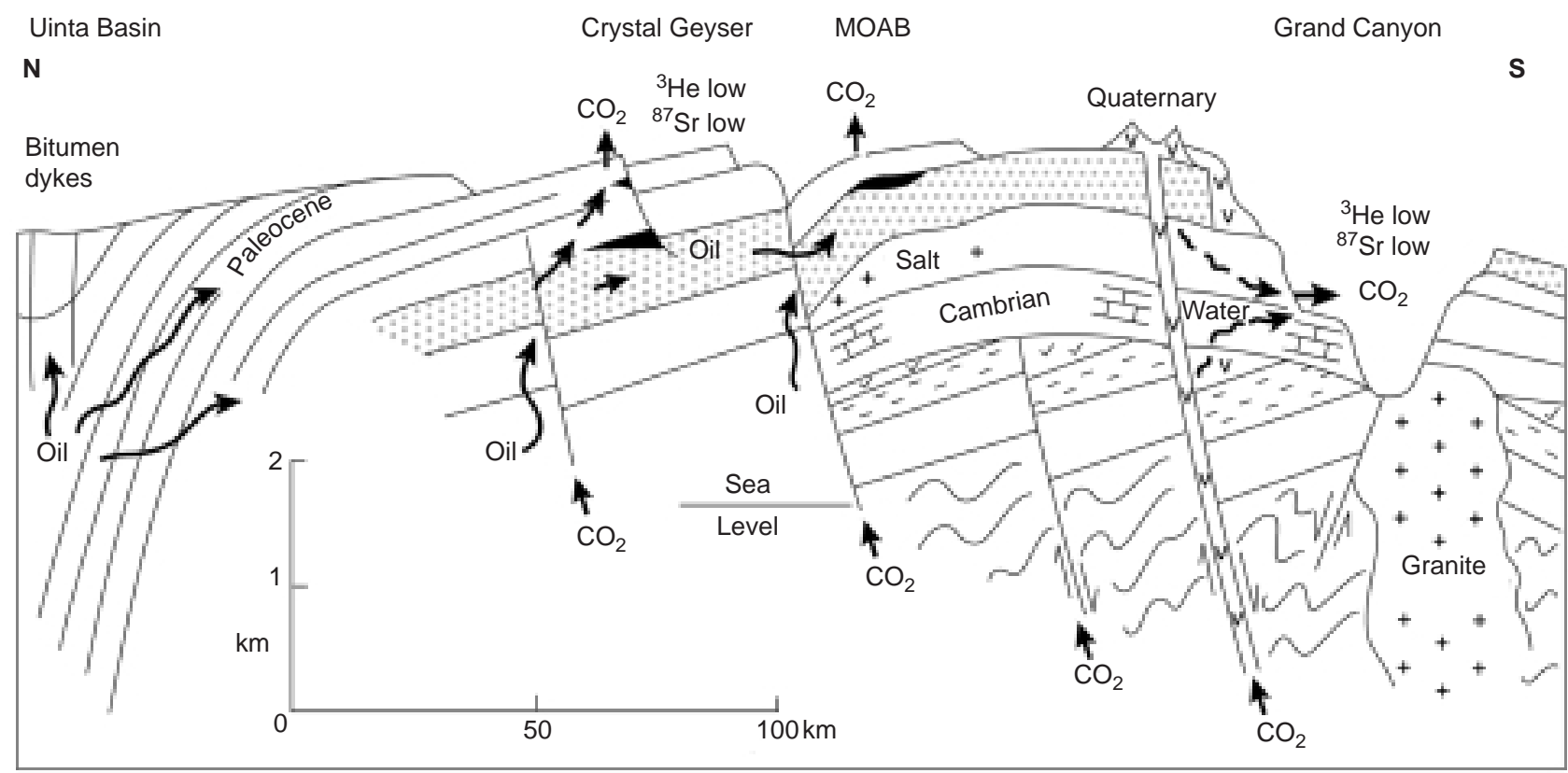

Figure 10

Cartoon sketch section across the Colorado Plateau, from north to south. The Tertiary Uinta hydrocarbon basin forms the northern limit and the Grand Canyon the present southern limit. Deep-sourced volcanic $\mathrm{CO}_{2}$ migrates vertically through reactivated basement structures with mantle He signatures, then is captured by horizontal sediment layering to migrate laterally through aquifers, with crustal helium signatures. $\mathrm{CO}_{2}$ may dissolve deep carbonates to super-saturate formation waters which form cool springs with abundant travertine at the surface.

$\mathrm{CaCO}_{3}$ by dissolution of limestone, and so precipitate travertine at spring sites. Travertine U-series ages range from modern, to older than $350 \mathrm{ka}$. The Colorado Plateau is abnormally rich in He with many gas fields containing 5-10\%, and up to $37 \mathrm{Gm}^{3}$ (1.5 tcf) of He in individual fields. The geological setting suggests that the origin of this $\mathrm{He}$ is from intrusive volcanics (Casey, 1983). Current work shows He isotope ratios with unmodified mantle signatures (Phinney et al., 1978, Ballentine, pers. comm., 2003). This is taken as evidence that basaltic volcanism is contributing $\mathrm{CO}_{2}$ and $\mathrm{He}$ to the active present-day basin system. Ballentine et al., (2001) have examined $\mathrm{He}$ accumulations associated with $\mathrm{CO}_{2}$ fields in west Texas. These fields are not on the Colorado Plateau, but lie in the foreland to the Alleghanian Orogeny. They show that $\mathrm{He}$ can act as a tracer of $\mathrm{CO}_{2}$ origins. Using $\mathrm{He} / \mathrm{CO}_{2}$ ratios they model diffusion to show that in some cases, $\mathrm{CO}_{2}$ is retained for geologically very long periods of $300 \mathrm{Ma}$.

\subsection{Bleached Sandstones and Large Scale $\mathrm{CO}_{2}$ Fluid System}

Ancient regional migrations of fluids have occurred in the Plateau area. We use four lines of evidence to e suggest that water and $\mathrm{CO}_{2}+\mathrm{H}_{2} \mathrm{~S}$ migration has occurred and oil migration may have followed similar carrier bed routes.

Firstly, the Plateau area is noted for its red-bed sandstones, which have been diagenetically bleached (Chan et al., 2000) along permeable zones (Figs. 11 and 13). In normal red-bed sandstones, iron exists as oxidised red $\mathrm{Fe}^{3+}$, which is poorlysoluble in aqueous fluids. This needs to be geochemically reduced to much more soluble $\mathrm{Fe}^{2+}$ to enable its aqueous transport. This means that reducing fluids have enabled the oxidised red iron to become soluble, and to be removed from the sandstone. In contrast to previous studies, we do not consider that such bleaching is produced directly by hydrocarbons - as we know of many red-coloured sandstones, which act as reservoirs for North Sea oil. An additional geochemical aspect is needed. We consider that $\mathrm{H}_{2} \mathrm{~S}$, commonly associated with $\mathrm{CO}_{2}$ in many of the modern springs, has reduced the iron and bleached the rock, this could originate from deeper thermal sulphate reduction. Organic acids or $\mathrm{CO}$ are also feasible reductants. Some iron is re-deposited locally as Fe and $\mathrm{Mn}$ oxides (Chan et al., 2000). However some thick aquifer sandstones, such as the 200-670 m aeolian Navajo, are so extensively bleached without local oxide growth, that they are incorrectly considered to be depositionally white. For example the $600 \mathrm{~m}$ Navajo sandstone is recorded to be red at its base in Zion Park, becoming progressively more white to its top $200 \mathrm{~m}$ (Biek et al., 2000, Fig. 4). Using satellite imagery it is possible to see bleached "migration fairways" in the regional Navajo sandstone where geochemically reducing fluids have entered structural highs "anticlines", which are now partly eroded (Beitler et al., 2003). Regional fluid flow must have effected mass-transport of iron. 


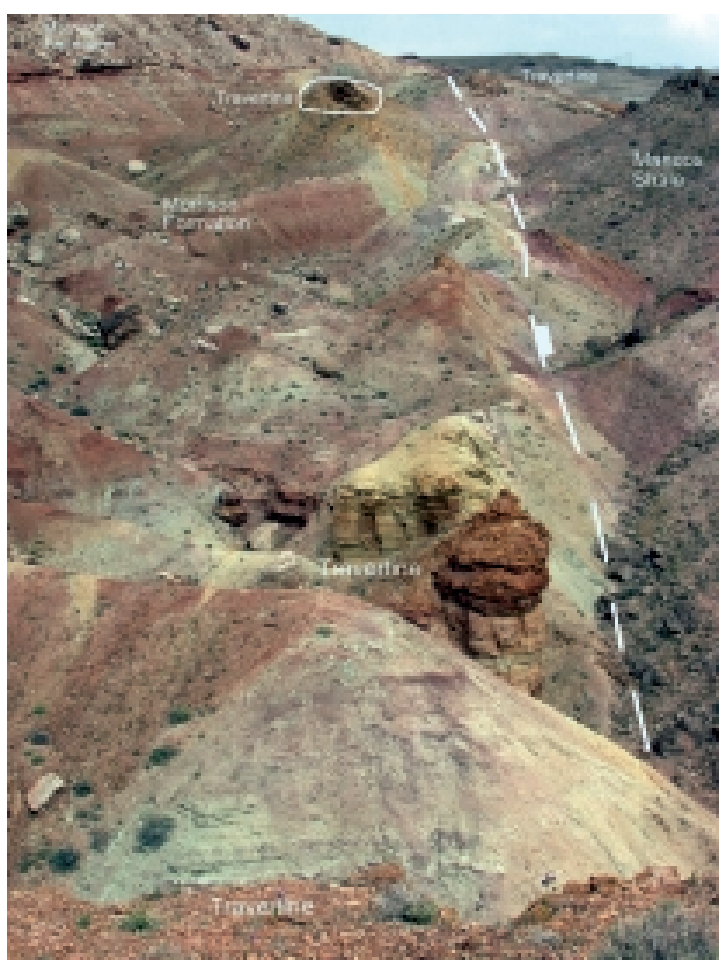

Figure 11

Little Grand Wash, Utah, showing line of fault with bleached mudrocks along its outcrop. Southern (downthrow) side is to right. Harder mounds are extinct travertine mounds about $10 \mathrm{~m}$ diameter.
Secondly, there is an almost total lack of bitumen residue. Although some oil has certainly migrated through these rocks, we consider this to be strong evidence of a natural $\mathrm{CO}_{2}$ drive producing natural "enhanced oil recovery" which dissolved any bitumen, to leave very little trace of residual hydrocarbon. We do not claim that bitumen is entirely absent - there are well known Tar Sand deposits in southern Utah (Huntoon, 1999), which contain up to $16 \mathrm{Gbbl}$ oil in White Rim sandstones, and there are also bitumen veinlets along the Moab fault. However compared with other exhumed hydrocarbon basins in the United Kingdom or United States, bitumen is, for some reason, lacking.

Thirdly, regional carrier beds can be inferred for $\mathrm{CO}_{2}+$ $\mathrm{H}_{2} \mathrm{~S}$, these are beneath mudrock seals. These form stratabound zones of white sandstone 1-2 m thick at the top of aeolian or fluvial red-bed sandstone units, with no depositional facies differences. These are the famous "White Rim" sandstones around canyon tops (Stokes, 1988). Excellent exposures show that these white zones are laterally extensive (tens kilometres), and underlie less-permeable sediments, which would have formed top-seal to laterally migrating lowdensity gas + water mixtures. We interpret such bleached sediments to be the diagenetic traces of regional carrier beds, analogous to carrier beds of similar extent and thickness inferred in conventional hydrocarbon systems. Diagenetic studies have shown hydrocarbon-filled fluid inclusions in diagenetic dolomite occur in these carrier beds, and suggest that any oil was derived from Mississipian source and emplaced about $44 \mathrm{Ma}$ (Huntoon et al., 1999).

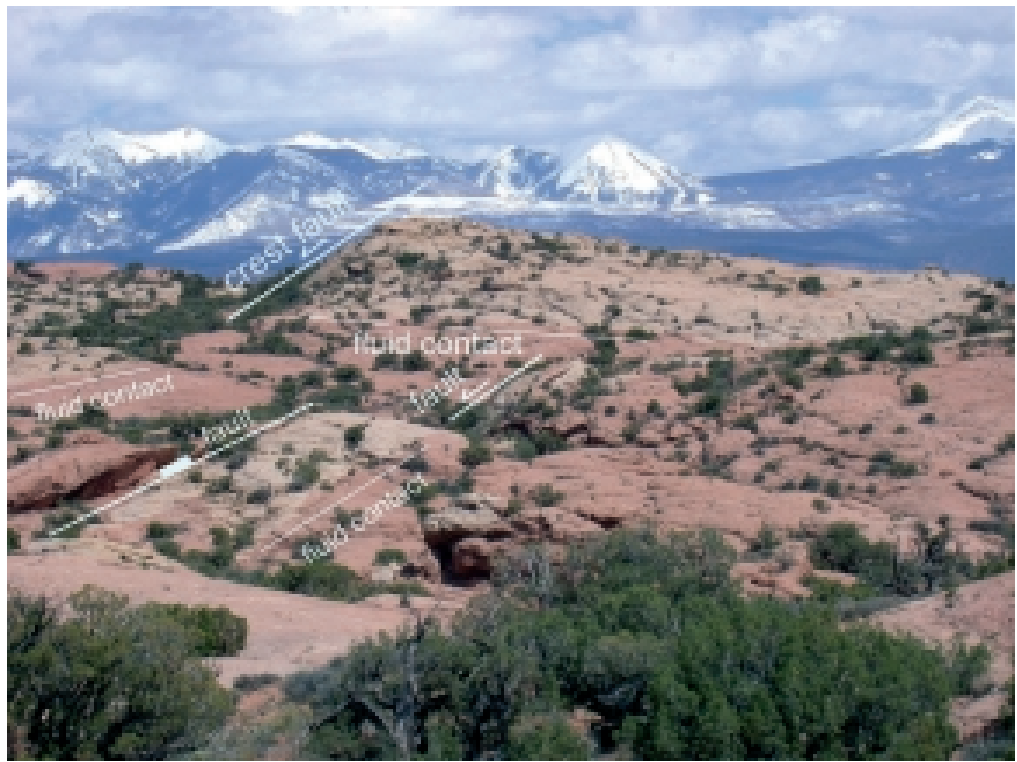

Figure 12

Crest of Moab anticline looking south, shows partly bleached red-bed sandstone, with left dipping surface in mid-distance defining a crestal fault block. Horizontal colour change, with white sandstone above, marks paleo-fluid contact. Several fault blocks are visible, each with a paleo-fluid contact, all sited on the anticlinal crest, within Entrada Sandstone (Moab Tongue Member). 


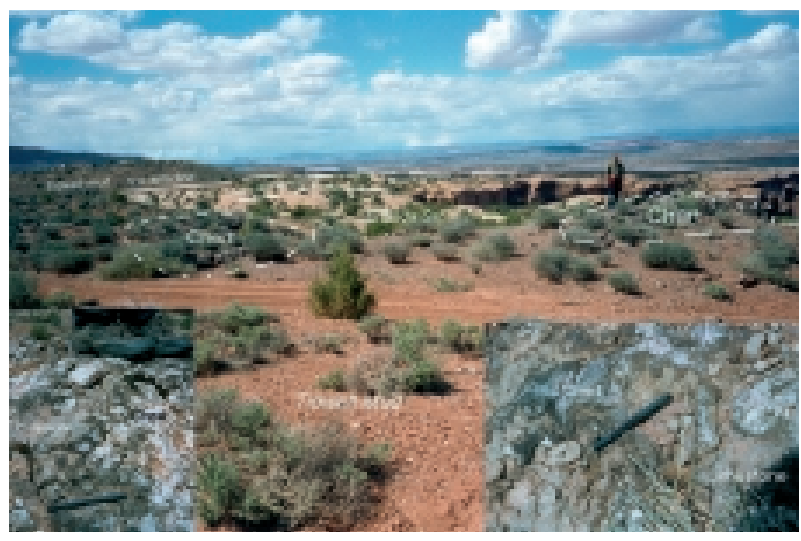

Figure 13

Crest of Moab anticline looking north, showing abundant chert replacement of calcite limestone in mudrocks directly overlying the anticline crest. This may be a position of paleo-leak-off vertically. Person stands on $4 \mathrm{~m}$ diameter mound, with similar chert mound $10 \mathrm{~m}$ to left. The Entrada sandstone is bleached white in the 2-4 m below overlying Tidwell Mudrock seal, which is overlain by Salt Wash Sandstone. Inset pictures show (left) detail of vertical section where chert replaces limestone; (right) detail of plan section where chert replaces limestone.

Fourthly, isotope signatures in diagenetic carbonate cements from these bleached sandstones are unlike those known to form from oxidation of hydrocarbon. Hydrocarbon oxidation produces signatures of $\delta^{13} \mathrm{C}=-30 \%$ (Macaulay et al., 2000). Isotopic signatures in Colorado bleached sandstones are seldom lower than $\delta^{13} \mathrm{C}=-10$ (Garden et al., 2001; Chan et al., 2000), which is compatible with an origin from organic acids, or mantle $\mathrm{CO}_{2}$, but not hydrocarbon. These $\delta^{13} \mathrm{C}$ values do not fit with the prediction that hydrocarbon oxidation caused iron reduction, to remove the iron from bleached sandstones. By contrast, these $\delta^{13} \mathrm{C}$ values are consistent with calcite produced by interaction with mantle $\mathrm{CO}_{2}$, in a process similar to the late calcite cement in the Miller North Sea oilfield (above).

\section{MODERN $\mathrm{CO}_{2}$ LEAKAGE UP FAULTS}

\subsection{Salt Wash, Utah}

These sites (labelled 1 on Fig. 8) occur south of the town of Green River in SE Utah, and have been reported by Shipton et al. (2005), Heath et al. (2003), and briefly investigated by the present authors. A number of sites occur with $\mathrm{CO}_{2}$ emissions at modern cool saline water springs, associated with small-throw east-west normal faults and their intersection with a north-plunging open anticline. The modern springs are expressed as travertine mounds, one is active today adjacent to the Green River, where the fault line is very well exposed.
A further five are active in the Great Salt Wash. At each locality a number of inactive ancient travertine mounds occur, typically $5 \mathrm{~m}$ thick and $20 \mathrm{~m}$ diameter, spaced along the fault (Fig. 11). Each travertine has been fed by a vertical $300 \mathrm{~mm}$ wide calcite vein, which turns horizontal within $4 \mathrm{~m}$ of the paleo-surface-suggesting a fluid pressure control. The final stages of veining form as aragonite indicating lower $\mathrm{CO}_{2}$ content, or poisoning by $\mathrm{SO}_{4}$ or $\mathrm{Mg}$ (Morse and Mackenzie, 1990). We consider that these springs are the shallowest expression of the $\mathrm{CO}_{2}$ basin system, and represent lateral migration through sandstone aquifers. Extensive bleaching of red sandstones and mudrocks occurs, with complete porefilling passive calcite cementation of sandstones around carbonate veins and travertines. Cementation decreases laterally away from each spring site, giving the opportunity to evaluate the effects of $\mathrm{CO}_{2}(\mathrm{aq})$-rock interaction at decreasing fluxes. At these cool near-surface temperatures it is probable that kinetic factors in mineral reactions play an increased role in the fluid-rock interactions at this fault-scale. Mudrocks within the fault zone and overlying shale are multicoloured, or contain bleaching cross-cutting bedding, suggesting post-depositional alteration (Fig. 11). Mudrock smear, $500 \mathrm{~mm}$ or thicker, exposed along the fault plane would conventionally be considered to seal a fault plane to fluid movement-however saline water $+\mathrm{CO}_{2}$ have obviously succeeded in finding or making a permeable pathway.

\subsection{Springerville-St Johns Arizona}

An extensive complex of $\mathrm{CO}_{2}$ springs has been reported by Moore et al., (2003), these are leakage through the crest of a NW-trending faulted anticline, controlled by basement structure (4 on Fig. 8). $\mathrm{CO}_{2}$ is reservoired in a series of Permian sandstones, limestones and dolomites. Extensive travertines occur over $250 \mathrm{~km}^{2}$, with kaolin precipitation and rare dawsonite. Several cool springs are active at the present day. Deposits are younger than Quaternary basalt and are interbedded with Pleistocene river gravels, so may date from 1 Ma ago.

\section{ANCIENT $\mathrm{CO}_{2}$ PALEO-TRAP: MOAB ANTICLINE}

This site lies north of the town of Moab in SE Utah, where salt movement in the Paradox Basin has formed faulted anticlines along basement fault trends affecting Triassic and younger sediments ( 2 on Fig. 8). The exceptionally wellexposed Moab fault and Moab anticline, are directly comparable in scale to subsurface hydrocarbon and $\mathrm{CO}_{2}$ structures on the Colorado Plateau at the present-day. The Moab fault is sometimes mapped as a south-east extension of the Salt Wash fault where $\mathrm{CO}_{2}$ is leaking at the present-day (above), and has been investigated by Garden et al. (2001) and the present authors. 
Garden et al., (2001) interpreted the Moab Anticline to be an exhumed paleo-hydrocarbon reservoir where palaeo-fluid contacts are revealed by horizontal colour changes cross-cutting bedding (Fig. 12). We agree with their interpretation that paleo-fluid contacts are recorded, but consider that $\mathrm{CO}_{2}$ also had a vital influence. This is shown by four lines of evidence.

Firstly, the carbon isotope signatures of calcite cements are similar both to those from $\mathrm{CO}_{2}$ cements in Miller oilfield North Sea, and those cited by Chan et al., (2000) from Utah. These are typical of mantle carbon values, not oxidation of hydrocarbon, as discussed above.

Secondly, the excellent surface exposures enable the morphology of carbonate cements to be traced out. These form unusual pipes within the sandstone body, extending up-dip from breached faults Garden et al., (2001). This is exactly as would be expected for up-dip buoyant leakage of $\mathrm{CO}_{2}$ charged waters. However this is a most unusual morphology for burial or hydrocarbon-related cements, which are usually concretionary or uniformly dispersed. Vertical pipes, which are cemented by haematite, are recorded by Chan et al., (2000) on the Moab anticline below the bleaching contact. These could represent the density-driven convection of $\mathrm{CO}_{2}(\mathrm{aq})$ waters derived from the structure crest. Numerical simulation of convection density overturn in porous media $\mathrm{CO}_{2}$ storage has been portrayed by Ennis-King and Peterson (2003).

Thirdly, the complete lack of bitumen, or dead oil, throughout the reservoir or at inferred palaeo-oil-water-contacts. This implies either that oil was never present, or that extremely efficient dissolution of bitumen in the reservoir occurred by $\mathrm{CO}_{2}$ fluids.

Fourthly, there is unusually extensive chert cementation, which selectively replaces limestone in the topseal mudrocks, but only on the crest of the anticline. Structure crests, such as this, are well-known to be the preferred positions of leak-off for buoyant hydrocarbons, or for geopressured fluids in deeply-buried hydrocarbon systems (Darby et al., 1996). We interpret the locations of chert at the Moab anticline, to be a record of vertical leakage of $\mathrm{CO}_{2}$-charged fluids through fractures at the crest of the structure (Fig. 13). Elsewhere at this stratigraphic horizon, sparse chert is known to occur, but is volumetrically minor (Hintze, 1988, Koeberl et al., 1999), so this anticline crest is anomalous. The localization of chert precipitation could be due to $\mathrm{CO}_{2}$ rich saline water experiencing a pressure drop upon breaching the mudrock seal overlying the geopressured sandstone reservoir. This process is known in several hydrothermal systems containing volcanic $\mathrm{CO}_{2}$, such as Broadlands (Simmons and Browne, 2001). It is also possible that silica precipitation processes may be controlled by salt-in and salt-out effects. These have been established during experimental studies of $\mathrm{H}_{2} \mathrm{O}-\mathrm{CO}_{2}$ brine systems at higher $\mathrm{P}$ and T. Crucially, these effects can not be predicted by most of the existing geochemical modelling codes. The fluid system $\mathrm{NaCl} / \mathrm{CaCl}_{2}-\mathrm{CO}_{2}-\mathrm{H}_{2} \mathrm{O} \pm$ oil shows that one homogeneous fluid exists at higher

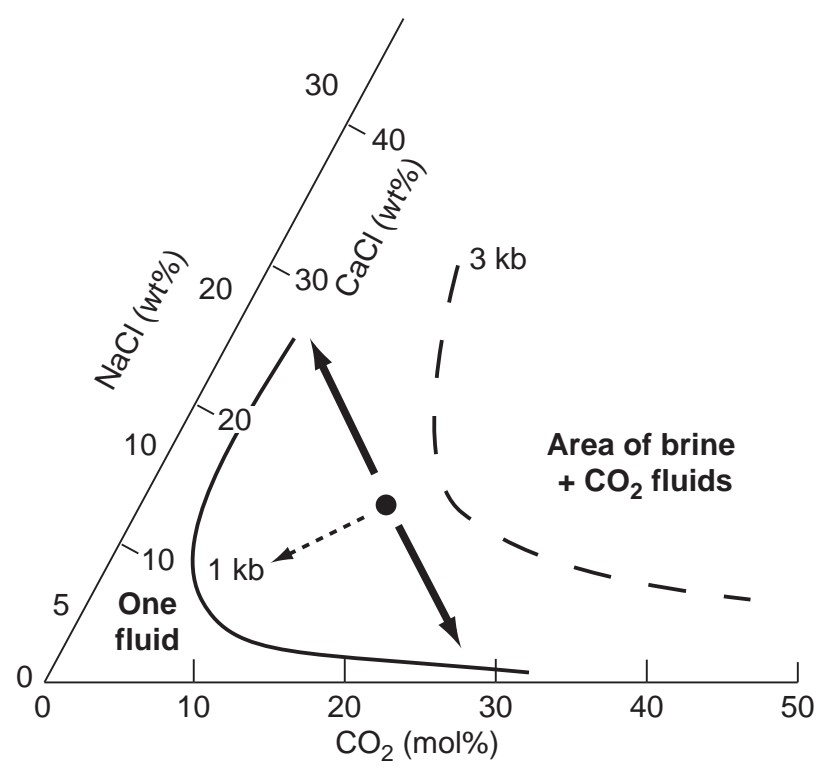

Figure 14

Phase relations in the $\mathrm{CO}_{2}$-brine system. When pressure drops the pore-filling fluid composition $(\bullet)$ un-mixes with each component following the arrows. This produces $\mathrm{CO}_{2}$ gas (which cannot carry dissolved $\mathrm{SiO}_{2}$ ), and brine with greater salinity (also with less $\mathrm{SiO}_{2}$ solubility). Thus silica can be forced to precipitate if pressure decreases-for example during leak-off from a geopressured trap into overlying normally-pressured sediment. This is one possible mechanism for chert precipitation at Moab anticline crest.

pressures. If pressure decrease occurs, by vertical leakage of fluid from a geopressured trap, then the phase boundary moves across the original mixture composition, and consequently exsolution results, to form $\mathrm{CO}_{2}$ gas and brine (Fig. 14). In both the $\mathrm{CO}_{2}$ gas and exsolved brine, the weight percent water is reduced so that $\mathrm{SiO}_{2}$ solubility decreases and silica will precipitate. The effect is enhanced if the brine becomes Ca-enriched (due here to host-rock change from mudrock to carbonate). Preliminary $1 \mathrm{~kb}, 400^{\circ} \mathrm{C}$ experiments show that silica solubility is greatly enhanced by dissolved $\mathrm{Na}_{2} \mathrm{SO}_{4}$. Both of these processes may be capable of self-sealing leakage from geopressured $\mathrm{CO}_{2}$ sequestration reservoirs.

\section{CONCLUSION}

- Storage of carbon dioxide emitted by fossil fuel use is essential to reduce future global warming. This can be undertaken in deep geological aquifers. Timescales of $10^{4}-10^{5} \mathrm{y}$ are needed for robust containment. This will require some monetary value to be given to $\mathrm{CO}_{2}$, but can be economically neutral on the United Kingdom economy. 
- An industrial scale experiment at Sleipner to inject $\mathrm{CO}_{2}$ into an aquifer $1000 \mathrm{~m}$ beneath the North Sea shows that existing oilfield technology is adequate. However the long-term performance of this storage site is not yet demonstrated. Monitoring shows leakage through thin mudrocks, even though the main seal remains robust.

- Natural analogues from North Sea oilfields show that high $\mathrm{CO}_{2}$ contents at $>4.0 \mathrm{~km}$ can be retained for geologically long periods of time. However the rock and fluids appear to be out of chemical equilibrium. This suggests that geochemical modelling softwares may need improved calibration to make accurate predictions at the timescales involved in nature.

- Natural analogues for $\mathrm{CO}_{2}$ migration, sealing, trapping and leakage occur in the United States Colorado Plateau. This enables study of exhumed carrier beds, exhumed reservoirs, and present day leakage associated with faults. Quantification of mineralogical changes at such sites may assist geochemical models to be calibrated to long natural time scales.

\section{ACKNOWLEDGEMENTS}

Thanks to Étienne Brosse and two other anonymous reviewers, for helping to improve the focus and clarity of this article.

\section{REFERENCES}

Allis, R.G., Chidsey, T., Gwynn, W., Morgan, C., White, C., Adams, M., and Moore, J. (2001) Natural $\mathrm{CO}_{2}$ reservoirs on the Colorado Plateau and Southern Rocky Mountains: candidates for $\mathrm{CO}_{2}$ sequestration. In: Proc. of 1st National Conference on $\mathrm{CO}_{2}$ Sequestration, DOE NETL, Washington, DC.

Anbeek, C. (1992) Surface roughness of minerals and implications for dissolution studies. Geochim. Cosmochim. Acta, 56, 1461-1469.

Ash, E., Archer, M., Barker, T., Boulton, G., Budd, A., Ewins, P., Fells, I., Hasard, J., Hewett, G., Harlock, J., Laughton, M. and Pearce, D. (2002) Economic instruments for the reduction of carbon dioxide emissions. Policy Document 26/02, Royal Society, London.

Baer, J.L. and Rigby, J.K. (1978) Geology of the Crystal Geyser and environmental implications of its effluent. Utah Geology, 2, 125-130, Utah Geological and Mineral Survey.

Baines, S.J. and Worden, R.H. (2004) The long term fate of $\mathrm{CO}_{2}$ in the subsurface: natural analogues for $\mathrm{CO}_{2}$ storage. In: Geological Storage of Carbon Dioxide for Emissions Reduction, Special Publication, Baines S.J. and Worden R.H. (eds.), Geological Society, London, in press.

Ballentine, C.J., Schoell, M., Coleman, D. and Cain, B.A. (2001) 300-Myr-old magmatic $\mathrm{CO}_{2}$ in natural gas reservoirs of the west Texas Permian basin. Nature, 409, 327-331.

Beitler, B., Chan, M.A. and Parry, W.T. (2003) Bleaching of Jurassic Navajo Sandstone on Colorado Plateau Laramide highs: evidence of exhumed hydrocarbon supergiants? Geology, 31, 1041-1044.

Biek, R.F., Willis, G.C., Hylland, M.D. and Doelling, H.H. (2000) Geology of Zion national park, Utah. In: Geology of Utah's National Parks and Monuments, Utah Geological
Association Publication, 28, 107-138, PO Box 520100 Salt Lake City, Utah.

Casey, T.A.L. (1983) Helium potential of the Four Corners area. In: Oil and Gas Fields of the Four Corners Area, Fassett J.E. (ed.), 3, Four Corners Geological Society.

Chadwick, R.A., Zweigel, P., Gregersen, U., Kirby, G.A., Holloway, S. and Johannessen, P.N. (2003) Geological characterisation of $\mathrm{CO}_{2}$ storage sites: lessons from Sleipner, northern North Sea. In: Greenhouse Gas Control Technologies, J. Gale and Y. Kaya (eds.), Elsevier, 321-326.

Chan, M.A., Parry, W.T. and Bowman, J.R. (2000) Diagenetic hematite and manganese oxides and fault-related fluid flow. AAPG Bulletin, 84, 1281-1310.

Crossey, L. (2002) Active springs and Quaternary travertines in Grand Canyon. Geol. Soc. America Ann. Mtg. Abs., 175-176.

Darby, D., Haszeldine, R.S., and Couples, G. (1996) Pressure cells and pressure seals in the Central North Sea. Marine and Petroleum Geology, 13, 865-878.

DTI (2003) Our Energy Future. White Paper CM5761, The Stationery Office, London.

Ennis-King, J. and Paterson, L. (2003) Rate of dissolution due to convective mixing in the underground storage of $\mathrm{CO}_{2}$. In: Greenhouse Gas Control Technologies, J. Gale and Y. Kaya (eds.), Elsevier, 1653-1656.

Fletcher, K.J. (2003a) The Central Brae field, Blocks 16/07a, 16/07b, UK North Sea. In: United Kingdom Oil and Gas fields, Commemorative Millenium Volume, Gluyas J.G. and Hichens H.M. (eds.), 183-190, Geological Society, London.

Fletcher, K.J. (2003b) The South Brae field, Blocks 16/07a, 16/07b, UK North Sea. In: United Kingdom Oil and Gas fields, Commemorative Millenium Volume. Gluyas J.G. and Hichens H.M. (eds.), 211-221, Geological Society, London.

Foresight (2002) Power Without Pollution: Zero Emission Power Generation, The Stationery Office, London.

Fuex, A.N. and Baker, D.R. (1973) Stable carbon isotopes in selected granitic mafic and ultramafic rocks. Geochim. Cosmochim. Acta, 37, 2509-2521.

Galimov, E.M. (1968) Isotopic composition of carbon in gases of the crust. International Geology Review, 11, 1092-1104.

Gambardo, M. and Donagemma, V. (2003) The T-Block fields, Block 16/17, UK North Sea. In: United Kingdom Oil and Gas fields, Commemorative Millenium Volume, Gluyas J.G. and Hichens H.M. (eds.), 369-382, Geological Society, London.

Garden, I.R., Guscott, S.C., Burley, S.D., Foxford, K.A., Walsh, J.J. and Marshall, J. (2001) An exhumed palaeo-hydrocarbon migration fairway. Geofluids, 1, 195-213.

Glennie, K.W. (1998) Petroleum Geology of the North Sea, $4^{\text {th }}$ ed., Blackwell, Oxford.

Gunter, W.D. (1996) Autoclave experiments and geochemical modelling. In: Aquifer Disposal of Carbon Dioxide, B. Hitchon (ed.), Geoscience Publishing, Alberta.

Hamblin, W.K. (1994) Late Cenozoic lava dams. Memoir 183, Geological Society America, Boulder.

Heath, J.E., Lachmar, T.E., Kolesar, P.T. and Evans, J.P. (2003) Hydrogeochemical characterisation of leaking $\mathrm{CO}_{2}$ charged fault zones in east-central Utah. In: Gas-Water-Rock Interactions, Abstract, 44, Institut francais du pétrole, Nov. 2003, Paris.

Hepple, R.P. and Benson, S.M. (2003) Implications of surface seepage on the effectiveness of geological storage of carbon dioxide as a climate change mitigation strategy. In: Greenhouse Gas Technologies, 1, J. Gale and Y. Kaya (eds.), Elsevier, 261-266.

Hintze, L.F. (1988) Geologic history of Utah. Geology Studies Spec. Publ. 7, Brigham Young Univ., Utah. 
Huntoon, J.E., Hansley, P.L., Naeser, N.D. (1999) The search for a source rock for the giant Tar Sand triangle accumulation, southeastern Utah. American Association of Petroleum Geologists Bulletin, 83, 67-495.

Holloway, S., Heederik, J.P., van der Meer, L.G.H., Czernichowski-Lauriol, I., Harrison, R., Lindeberg, E., Summerfield, I.R., Rochelle, C., Schwarzkopf, T., Kaarstad, O., Berger, B. (1996) The underground disposal of carbon dioxide. Summary Report. Joule II CT92-0031, BGS Keyworth, ISBN 0852722796 .

IEA (2004) International Energy Annual, Energy Information Administration, Washington, USA. www.eia.doe.gov

IPCC (2001) Climate Change 2001: Synthesis Report, Contribution of Working Groups I, II and III to the Third Assessment Panel of the Intergovernmental Panel on Climate Change, R.T. Watson (ed.), Cambridge University Press. www.ipcc.ch

Johnson, J.W. (2003) $\mathrm{CO}_{2}$ Reservoirs: are they natural analogs to engineered geologic storage sites? Ann. Mtg., Abs., American Association of Petroleum Geologists, Tulsa, OK.

Johnson, J.W. and Nitao, J.J. (2003) Reactive transport modelling of geologic $\mathrm{CO}_{2}$ sequestration at Sleipner. In: Greenhouse Gas Control Technologies, J. Gale and Y. Kaya (eds.), Elsevier, 327332.

Kheshgi, H.S., Jain, A.K., Wuebbles, D.J. (1966) Accounting for the missing carbon-sink with the $\mathrm{CO}_{2}$-fertilization effect. Climatic Change, 33, 1, 31-62.

Knauss, K.G., Johnson, J.W., Steefel, C.I., and Nitao, J.J. (2001) Evaluation of the impact of $\mathrm{CO}_{2}$, aqueous fluid, and reservoir rock interactions on the geologic sequestration of $\mathrm{CO}_{2}$, with special emphasis on economic implications. In: Proc. of 1st National Conference on $\mathrm{CO}_{2}$ Sequestration, DOE National Energy Technology Laboratory USA, Washington, DC, 26-37.

Koeberl, C., Plescia, J.B., Hayward, C.L., Reimold, W.U. (1999) A petrographic study of quartzose rocks from Upheaval Dome. Meteoritics and Planet Science, 34, 861-868.

Korbol, R., Kaddour, A. (1995) Sleipner-Vest $\mathrm{CO}_{2}$ disposalinjection of removed $\mathrm{CO}_{2}$ into the Utsira Formation. Energy Conversion and Management, 36, 509-512, Jun-Sep 6-9.

Lee, M.R., Hodson, M.E., Parsons, I. (1998) The role of intragranular microtextures and microstructures in chemical and mechanical weathering: direct comparisons of experimentally and naturally weathered alkali feldspars. Geochim. Cosmochim. Acta, 62, 2771-2788.

Lindeberg, E. (2003) The quality of a $\mathrm{CO}_{2}$ repository: what is the sufficient retention time of $\mathrm{CO}_{2}$ storged underground. In: Greenhouse Gas Technologies, 1, J. Gale and Y. Kaya (eds.), Elsevier, 255-260.

Macaulay, C.I., Haszeldine, R.S. and Fallick, A.E. (1992) Diagenetic pore waters stratified for at least 35 million years: Magnus oil field, North Sea. Bulletin American Association Petroleum Geologists, 76, 1625-1634.

Macaulay, C.I., Haszeldine, R.S. and Fallick, A.E. (1993) Distribution, chemistry, isotopic composition and origin of diagenetic carbonates: Magnus sandstone, North Sea. J. Sedimentary Petrology, 63, 33-43.

Macaulay, C.I., Fallick, A.E., McAulay, G.E., Watson, R.S., Stewart, R.N.T. and Haszeldine, R.S. (2000) Oil migration makes the difference: regional distribution of carbonate cement $\delta^{13} \mathrm{C}$ in northern North Sea Tertiary sandstones. Clay Minerals, 35, 7380.

McLaughlin, O.M., Haszeldine, R.S. and Fallick, A.E. (1996) Quartz diagenesis in layered fluids in the South Brae Oilfield, North Sea. In: Siliclastic Diagenesis Fluid Flow: Concepts and Applications, L. Crossey, Loucks and Totten (eds.), Society of
Economic Paleontologists and Mineralogists Special Publication 55, 103-113.

Mackenzie, F.T. Lerman, A., and Ver, L.M.B. (2001) Recent past and future of the global carbon cycle. In: Studies in Geology, Gerhard L.C., Harrison W.E. and Hanson B.M. (eds.), 47, 51-82, American Association of Petroleum Geologists, Tulsa, OK.

Magoon, L.B. and Valin, Z.C. (1994) Overview of petroleum system case studies. In: The Petroleum System - from Source to Trap, Magoon L.B. and Dow W.G. (eds.), 329-339, Memoir 60, American Association of Petroleum Geologists, Tulsa, OK.

Marchand, A.M.E., Haszeldine, R.S., Smalley, P.C., Macaulay, C.I. and Fallick, A.E. (2001) Evidence for reduced quartz cementation rates in oil-filled sandstones. Geology, 29, 915-918.

Moore, J, Allis, R., Lutz, S., and Adams, M. (2003) Investigations of $\mathrm{CO}_{2}$ mobility in natural reservoirs beneath the Colorado Plateau and Southern Rocky Mountains. Second Annual Conference on Carbon Sequestration, NETL Proceedings, May 5-8, Alexandria, Virginia, 22, http://geology.utah.gov/

Morse, J.W. and Mackenzie, F.T. (1990) Geochemistry of sedimentary carbonates. Developments in Sedimentology, 48, Elsevier.

Parmesan, C. (2001) Global Warming: Impacts on Wildlife and Society, www.geo.utexas.edu/outreach/lectures.html Outreach lecture, University of Austin, Texas.

Pederson, J., Karlstrom, K., Sharp, W. and McIntosh, W. (2002) Differential incision of the Grand Canyon related to Quaternary faulting-Constraints from U-series and Ar/Ar dating. Geology, 30, 739-742.

Phinney, D., Tennyson, J. and Frick, V. (1978) Xenon in $\mathrm{CO}_{2}$ well gas revisited. Journal of Geophysical Research, 83, 23132319.

Ranaweera, H.K.A. (1987) Sleipner Vest. In: Geology of the Norwegian Oil and Gas Fields, 253-264, A.M. Spencer (ed.), Graham and Trotman,

Roberts, L.W. and Godfrey, J.A. (1994) History of Bravo Dome $\mathrm{CO}_{2}$-discovery and early development. New Mexico Bureau of Mines and Mineral Resources Bulletin, 150, 9-12.

Shipton, Z.K., Evans, J.P., Dockrill, B., Heath, J., Williams, A., Kirchner, D. and Kolesar, P.T. (2005) Natural leaking $\mathrm{CO}_{2}$ charged systems as analogs for failed geologic storage reservoirs. In: The $\mathrm{CO}_{2}$ Capture and Storage Project (CCP), ll, D.C. Thomas and S.M. Benson (eds.), Elsevier, in press.

Shmulovich, K.I., Tkachenko, S.I., Plyasunova. N.V. (1995) Phase equilibria in fluid systems at high pressures and temperatures. In: Fluids in the Crust, Shmulovich K.I., Yardley B.W.D., Gonchar G. (eds) 193-214, Chapman and Hall, London.

Simmons, S.F., Browne, P.R.L. (2001) Hydrothermal minerals and precious metals in the Broadlands-Ohaaki geothermal system; implications for understanding low-sulfidation epithermal environments. Economic Geology, 95, 971-999.

Spence, S. and Kreutz, H. (2003) The Kingfisher field, Block 16/8a, UK North Sea. In: United Kingdom Oil and Gas fields, Commemorative Millenium Volume, Gluyas J.G. and Hichens H.M. (eds.), 305-314, Geological Society, London.

Stokes, W.L. (1988) Geology of Utah, $2^{\text {nd }}$ ed., Utah Geological and Mineral Survey.

USGS (2003) Petroleum systems and geologic assessment of oil and gas in the Uinta-Piceance Province, Utah and Colorado. Digital Data Series DDS-69-B Version 1.0, US Geological Survey, Denver.

Velbel, M.A. (1993) Constancy of silicate mineral weathering ratios between natural and experimental weathering: implications for hydrologic control of differences in absolute rate. Chemical Geology, 105, 89-99. 
Watson, M.N., Zwingmann, N. and Lemon, N.M. (2003) The Ladbroke Grove-Katnook carbon dioxide natural laboratory: a recent $\mathrm{CO}_{2}$ accumulation in a lithic sandstone reservoir. In: Greenhouse Gas Technologies, 1, J. Gale and Y. Kaya (eds.), Elsevier, 435-440.

White, A.F. and Brantley, S.L. (2003) The effect of time on the weathering of silicate minerals: why do weathering rates differ in the laboratory and field? Chemical Geology 202, 479-506.

Wigley, T.M.L. (1998) The Kyoto protocol: $\mathrm{CO}_{2}, \mathrm{CH}_{4}$ and climate implications. Geophysical Research Letters, 25, 13, 2285-2288.
Yohe, G., Andronova, N., and Schlesinger, M. (2004) To hedge or not against an uncertain climate future? Science, 306, 416417.

Zweigel, P, Arts, R., Bidstrup, T., Chadwick, A., Eiken, O., Gregersen, U., Hamborg, M., Johanessen, P., Kirby, G., Kristensen, L. and Lindeberg, E. (2001) Results and experiences from the first industrial-scale underground $\mathrm{CO}_{2}$ sequestration case, Sleipner. AAPG Ann. Mtg., Extended Abs., Denver.

Final manuscript received in January 2005 